\title{
Assessment of lipid, hepatic, and thyroid parameters with serum perfluorooctanoate (PFOA) concentrations in fluorochemical production workers
}

\author{
Geary W. Olsen · Larry R. Zobel
}

Received: 4 September 2006/Accepted: 1 June 2007/Published online: 29 June 2007

(C) Springer-Verlag 2007

\begin{abstract}
Objectives Perfluorooctanoic acid (PFOA) results in peroxisome proliferator mediated effects in rats and mice resulting in hypolipidemia but not in monkeys. Counterintuitive modestly positive associations between PFOA and cholesterol levels in production workers have been inconsistently reported. The purpose of this assessment was to examine this association in male workers who manufactured or used PFOA at three facilities.

Methods Subjects were male employee voluntary participants of a fluorochemical medical surveillance program who provided blood samples for serum measurement of PFOA (perfluorooctanoate) and various lipid, hepatic, and thyroid parameters. Statistical analyses included multiple and logistic regression and analysis of covariance.

Results A total of 506 employees, who did not take cholesterol-lowering medications (93\% of all male participants), were analyzed. Serum PFOA concentrations ranged from 0.007 to $92.03 \mu \mathrm{g} / \mathrm{ml}$ [arithmetic mean $2.21 \mu \mathrm{g} / \mathrm{ml}$ (95\% confidence interval 1.66-2.77), median $1.10 \mu \mathrm{g} / \mathrm{ml}]$. Adjusted for age, body mass index, and alcohol usage in regression analyses, PFOA was not statistically significantly $(P>0.05)$ associated with total cholesterol or low-density lipoproteins (LDL). High-density lipoproteins (HDL) were significantly negatively $(P<0.01)$ associated with PFOA for the three facilities combined but not by individual sites, indicating the overall result was likely a consequence of residual confounding due to different demographic profiles at these sites. Serum triglycerides were significantly positively associated with
\end{abstract}

G. W. Olsen $(\bowtie) \cdot$ L. R. Zobel

Medical Department, 3M Company,

Mail Stop 220-6W-08, St Paul, MN 55144, USA

e-mail: gwolsen@mmm.com
PFOA but not consistently by locations. There were no statistically significant associations observed between PFOA and hepatic enzymes for the three facilities combined although some modest positive associations were observed between PFOA and hepatic enzymes at one of the three facilities. Analyses of all locations showed no associations with TSH or T4 and PFOA. A negative association was observed for free $\mathrm{T} 4$ and positive association for T3; however, the findings were well within these assays' normal reference ranges.

Conclusion There was no evidence that employees' serum PFOA concentrations were associated with total cholesterol or LDL. A negative association with HDL was explained by demographic differences across the three locations. Several explanations are offered for the inconsistent triglyceride associations with PFOA including both methodological as well as biological possibilities.

Keywords Perfluorooctanoate $\cdot$ PFOA $\cdot$ Fluorochemicals . Cholesterol · Lipids

\section{Introduction}

The ammonium salt of perfluorooctanoic acid (APFO), which rapidly dissociates in blood to perfluorooctanoate $\left(\mathrm{PFOA}, \mathrm{C}_{7} \mathrm{~F}_{15} \mathrm{COO}^{-}\right.$), has been used as a processing aid in the production of various fluoropolymers. The widespread presence of PFOA in the blood of the general population (Calafat et al. 2006) has resulted in assessments of sources of exposure including industrial production, indirect sources including atmospheric production, and transport of telomer precursors (De Silva and Maybury 2006).

As a manufacturer and user of APFO until its phase-out beginning in 2000 , the $3 \mathrm{M}$ Company (3M) has reported 
several periodic medical surveillance analyses of its fluorochemical production workers at its Antwerp, Belgium; Cottage Grove, MN; and Decatur, AL manufacturing facilities (Ubel et al. 1980; Gilliland and Mandel 1996; Olsen et al. 1998, 2000, 2003a). These analyses compared workers' clinical chemistry and hormone results in relation to their serum measurements of either PFOA or perfluorooctanesulfonate (PFOS, $\mathrm{C}_{8} \mathrm{~F}_{17} \mathrm{SO}_{3}^{-}$).

In one of the aforementioned analyses, Olsen et al. (2003a) reported a positive association between PFOA and serum cholesterol and triglycerides among participants of a fluorochemical medical surveillance program conducted in 2000 at the 3M Antwerp and Decatur facilities. They considered this a spurious finding given the toxicological evidence in mice and rats that shows PFOA, a peroxisome proliferator alpha receptor agonist (PPAR $\alpha$ ), exerts effects including increased beta-oxidation of fatty acids, inhibition of the secretion of very low-density lipoproteins and cholesterol from the liver, and a reduction of cholesterol and triglycerides in serum and accumulation of lipids in the liver (Maloney and Waxman 1999; Xie et al. 2003; Kennedy et al. 2004). No associations were reported between PFOA and either serum cholesterol or triglycerides for the Cottage Grove male employees who participated in the same fluorochemical medical surveillance program in 2000 (Olsen et al. 2003c).

In response to these occupational findings, Costa (2004) reported preliminary cross-sectional analyses of data collected from 2000 to 2004 of approximately 40 (per year) Italian fluorochemical production workers. Costa observed a modest increase of total cholesterol in workers exposed to PFOA. There was no increase of other lipids, including triglycerides, but the fraction of non-high density lipoprotein (non-HDL) cholesterol appeared elevated. Costa suggested his findings might be consistent with the hypothesis that PFOA could influence cholesteryl ester transfer protein (CETP), a plasma glycoprotein that facilitates the transfer of cholesteryl esters from apolipoprotein A-containing lipoprotein (HDL) to apolipoprotein B-containing lipoproteins (Brousseau et al. 2004).

Kaplan (2004) summarized a cross-sectional analysis of 782 male and 243 female (combined eligible population 1,863 ) workers with potential exposure to PFOA at the DuPont de Nemours Co. (DuPont) Parkersburg, West Virginia facility. The highest measured PFOA concentration reported was approximately $10 \mu \mathrm{g} / \mathrm{ml}$ with the average less than $1 \mu \mathrm{g} /$ $\mathrm{ml}$. Statistically significant positive associations were identified for total cholesterol, low-density lipoproteins (LDL) and triglycerides with serum PFOA concentrations although the percent variation explained was also low. No association, however, was seen with the HDL fraction thereby not supporting a role between PFOA and CETP. Worker EKG results and $\mathrm{C}$-reactive protein measurements were also not associated with PFOA. Although Kaplan offered no additional hypotheses or suggested causal models (Hernán et al. 2002), PFOA has been shown to bind or be carried on blood albumin (Han et al. 2003) and beta-lipoproteins (KerstnerWood et al. 2003) in the rat, monkey and human; thus, a positive non-causal correlation remains a possibility.

Re-examination of the Olsen et al. (2003a) analyses suggested some limitations as they would relate to testing the hypothesis that PFOA is positively associated with total cholesterol and its non-HDL sub-fractions. First, the analyses were not stratified by cholesterol lowering medication status. A positive association could be masked by inclusion of subjects whose serum cholesterol levels have been reduced by medication if such an increase was, in part, associated with higher PFOA concentrations. Second, LDL calculations were not restricted to those instances where serum triglycerides were $<400 \mathrm{mg} / \mathrm{dl}$. The potential for bias in the LDL calculation steadily increases with higher triglyceride levels (Nakanishi et al. 2000). Third, the Antwerp and Decatur facility study concentrated primarily on PFOS, not PFOA. Both PFOS and PFOA have been shown to result in hypolipidemia in rats at high concentrations and thus the causal model hypothesized in these earlier analyses concentrated on testing for this effect, not hyperlipidemia. Finally, there was no overall analysis of the three manufacturing facilities (Antwerp, Belgium; Cottage Grove, MN; and Decatur, AL) as the Cottage Grove analysis has historically been reported separately (Ubel et al. 1980; Gilliland and Mandel 1996; Olsen et al. 2000, 2003a) due to differences in fluorochemical production activities.

The purpose of this study was to analyze the $3 \mathrm{M}$ fluorochemical medical surveillance program data collected in 2000 in order to examine the hypothesis that PFOA may be positively associated with increased cholesterol, LDL, and triglyceride levels across the three $3 \mathrm{M}$ fluorochemical production facilities. Analyses focused on male employees who self-reported that they were not taking cholesterol lowering medications in order to minimize unexplained bias introduced by including participants taking such medication. Because PFOS concentrations were not previously associated with lowered serum cholesterol (Olsen et al. 2003a), PFOS was not considered an important potential confounding variable in these PFOA analyses. Three covariates were: age, BMI and alcohol. In addition to the lipids assayed, hepatic enzyme and thyroid tests were also analyzed. Serum triglyceride levels were also considered a potential confounder with hepatic enzyme analyses (Clark et al. 2003).

\section{Materials and methods}

The 2000 fluorochemical medical surveillance program at $3 \mathrm{M}$ was available on a voluntary basis to all Antwerp, 
Decatur, and Cottage Grove chemical plant employees and those with site-wide responsibilities (e.g., environmental, health and safety workers). Informed consent was obtained to measure specific fluorochemical concentrations in the blood of program participants, including PFOA. The number of individuals eligible (i.e., potential to have had occupationally related exposure) for the program included approximately 340 Antwerp, 400 Decatur, and 200 Cottage Grove employees.

Clinical chemistry variables considered in the analyses were: alkaline phosphatase (IU/l), gamma glutamyl transferase (GGT, IU/l), aspartate aminotransferase (AST, IU/1), alanine aminotransferase (ALT, IU/l), total and direct bilirubin $(\mathrm{mg} / \mathrm{dl})$, blood glucose $(\mathrm{mg} / \mathrm{dl})$, cholesterol $(\mathrm{mg} / \mathrm{dl})$, LDL (mg/dl), HDL (mg/dl), and triglycerides (mg/dl). These measurements were performed at Allina Laboratories (St Paul, MN). LDL was an indirect calculation using the Friedewald formula (Friedewald et al. 1972) [LDL = total cholesterol - HDL - (triglycerides/5)] when serum triglycerides did not exceed $400 \mathrm{mg} / \mathrm{dl}$. Thyroid stimulating hormone (TSH; $\mu \mathrm{IU} / \mathrm{ml})$; serum thyroxine $(\mathrm{T} 4 ; \mu \mathrm{g} / \mathrm{dl})$; free thyroxine (free $\mathrm{T} 4 ; \mathrm{ng} / \mathrm{dl}$ ) and serum triiodothyronine (T3; $\mathrm{ng} / \mathrm{dl}$ ) were also analyzed. These thyroid related hormones were measured by LabCorp (Kansas City, MO). Thyroid hormone analyses excluded five individuals who were already diagnosed with thyroid-related conditions and likely taking medication. Results, however, did not differ if these individuals were included in the analyses.

PFOA concentrations were also compared to frequency of the metabolic syndrome in the study participants. Clinical identification of the metabolic syndrome in men includes any three of the following: waist circumference $>40$ in. (surrogate $\mathrm{BMI} \geq 30$ ); triglycerides $\geq 150 \mathrm{mg} / \mathrm{dl}$; HDL $<40 \mathrm{mg} / \mathrm{dl}$; blood pressure $\geq 130 / 85 \mathrm{mmHg}$; and fasting glucose $\geq 110 \mathrm{mg} / \mathrm{dl}$ (Expert Panel 2001). The present study definition of the metabolic syndrome included any three of the following four: BMI $\geq 30$; triglycerides $\geq 150 \mathrm{mg} / \mathrm{dl} ; \quad \mathrm{HDL}<40 \mathrm{mg} / \mathrm{dl} ; \quad$ and fasting glucose $\geq 110 \mathrm{mg} / \mathrm{dl}$.

At the time of the analyses that were done in 2000-2001 by Tandem Labs (formerly Northwest Bioanalytical, Salt Lake City, UT), the analytical methods used were comparable to those reported by Hansen et al. (2001). The analytical method consisted of a liquid:liquid extraction procedure followed by evaporation and reconstitution of the extract residue with $30: 7020 \mathrm{mM}$ ammonium acetate in water:20 mM ammonium acetate in methanol (v/v). Eight or more calibration standards were prepared on the day of each run by adding $100 \mu$ l of blank human serum and $400 \mu \mathrm{l}$ of $50 \mathrm{mM}$ ammonium acetate in water to polypropylene tubes. After a brief vortex mixing, $10.0 \mu \mathrm{l}$ of the appropriate spiking solution was added. In addition, blank serum samples, both with and without internal standard (tetra hydro-PFOS) were added. Samples were analyzed by liquid chromatography/tandem mass spectrometry using a PE Sciex API 3000 (Applied Biosystems, Foster City, CA). The instrument was operated in the multiple reaction monitoring mode under optimized conditions for detection of PFOA ions formed by turbionspray ionization. All PFOA measurements were reported above the lower limit of quantitation $(5.8 \mathrm{ng} / \mathrm{ml})$.

Statistical analyses included analysis of variance, analysis of covariance, logistic regression, and multiple regression using JMP (Cary, NC) and Stata (College Station, TX) software. Age, BMI and alcohol (drinks per day) were considered covariates in the multivariable models. For analysis of hepatic enzymes, serum triglycerides were also considered a covariate. Distributions were examined to assess normality using non-transformed variables and their transformations (log, square root, inverse). In general, log transformations improved normality assumptions of response and explanatory variables and thus multiplicative models (log transformations of explanatory and response variables) were considered applicable. For the log transformation of alcohol, 0.1 was added to drinks per day to prevent the $\log$ of 0 . Goodness of fit statistics, multicollinearity, and residual plots were examined to detect model inadequacies. Crude and adjusted odds ratios for PFOA categorized by deciles were determined via logistic regression analyses for reference range values of the response variable.

A comprehensive report is publicly available elsewhere that details the present study methods and results (Olsen and Zobel 2006).

\section{Results}

A total of 552 employees (Antwerp $=206$; Cottage Grove $=131$; Decatur $=215$ ) participated from these facilities representing approximately $60 \%$ of Antwerp, $50 \%$ of Decatur and 65\% of Cottage Grove eligible employees. Demographic characteristics of those eligible employees who did not participate are not known although substantial differences between participants and non-participants are unlikely given the routine practice of offering voluntary medical surveillance programs at these facilities for more than 20 years.

Of the 552 employee participants at these 3 facilities, $506(92 \%)$ self-reported that they did not take cholesterollowering medications: 196 (95\%) for Antwerp, 122 (93\%) for Cottage Grove, and 188 (87\%) for Decatur. Results will focus on these 506 participants.

Presented in Table 1 are measures of central tendency for the 506 participants for PFOA, PFOS, demographic factors and the clinical chemistries. The number and per- 


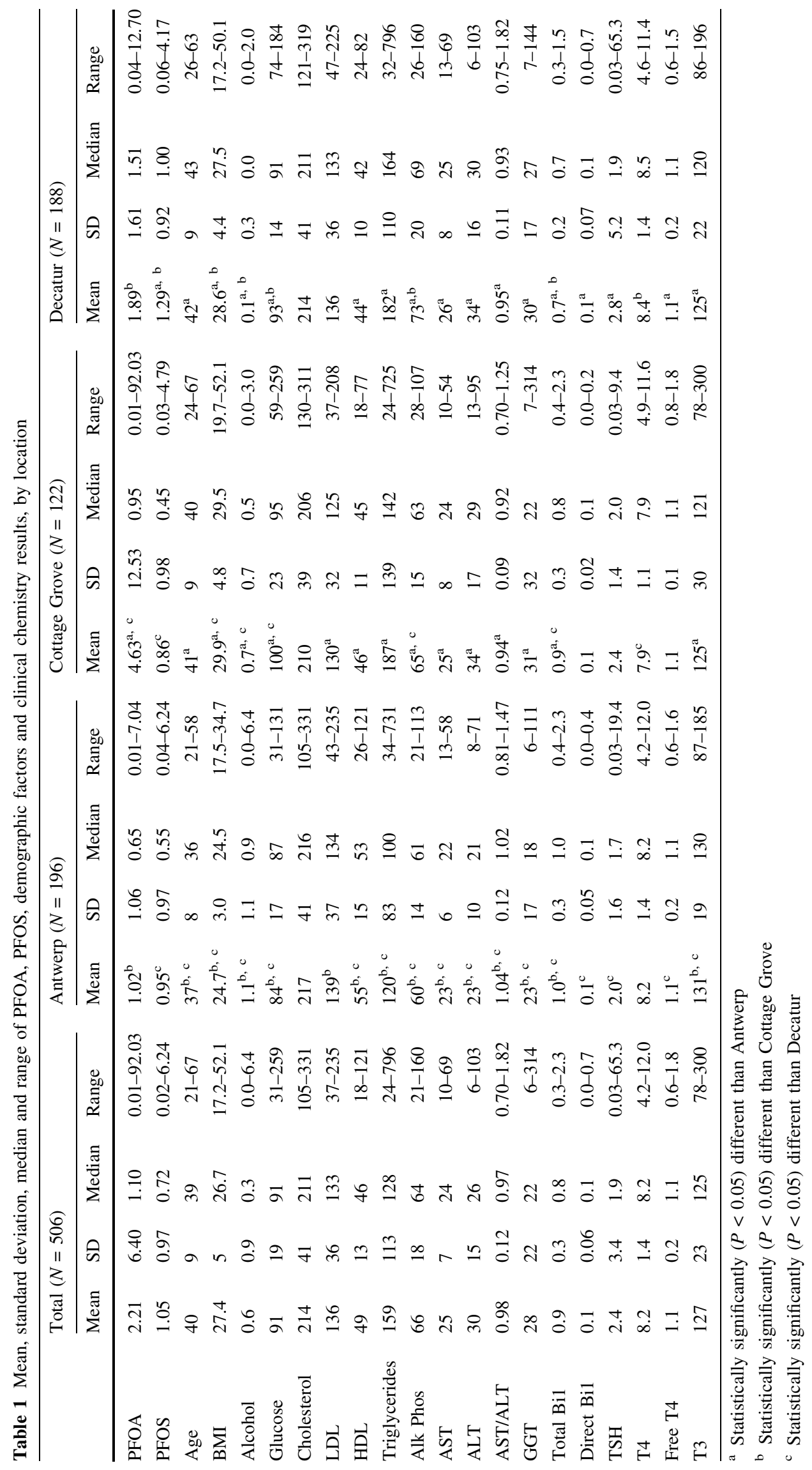


cent of employees by specific reference points for demographic factors and clinical chemistry findings are presented in Table 2. Besides their younger age, there were substantially fewer Antwerp employees (5\%) who would be categorized as obese (BMI $\geq 30)$ compared to Cottage Grove (44\%) or Decatur (32\%) employees. More than $40 \%$ of Antwerp and Cottage Grove employees reported drinking one alcoholic beverage per day or more compared to only $1 \%$ of Decatur employees. There were regional cultural/lifestyle practices that likely account for this difference in alcohol consumption. Other statistically significant differences between the three locations were observed for blood glucose, HDL, triglycerides, alkaline phosphatase, ALT, total bilirubin, and the 'metabolic syndrome'. The higher percentage of Antwerp male employees with total bilirubin $>1.5 \mathrm{mg} / \mathrm{dl}$ has been attributed to the likely greater prevalence of Gilbert's syndrome (Olsen et al. 1999). Only $1 \%$ of the Antwerp employees were categorized as having the 'metabolic syndrome' compared to 20 and $13 \%$ among the Cottage Grove and Decatur employees, respectively.

Serum PFOA concentrations for the 506 employees ranged from 0.007 to $92.03 \mu \mathrm{g} / \mathrm{ml}$ [arithmetic mean $2.21 \mu \mathrm{g} / \mathrm{ml}$ (95\% confidence interval 1.66-2.77), median $1.10 \mu \mathrm{g} / \mathrm{ml}$. PFOA results are categorized by deciles in Table 3. Mean PFOA decile concentrations ranged from the lowest decile of $0.06 \mu \mathrm{g} / \mathrm{ml}$ (range $0.007-0.13 \mu \mathrm{g} / \mathrm{ml}$ ) to the highest decile of $12.15 \mu \mathrm{g} / \mathrm{ml}$ (range 3.71-92.03 $\mu \mathrm{g}$ / $\mathrm{ml}$ ) with corresponding median values of 0.06 and $4.94 \mu \mathrm{g} /$ $\mathrm{ml}$, respectively.

The distributions of demographic factors by PFOA decile are presented in Table 4 . There were higher percentages of Antwerp employees in the first three deciles and lower percentages in the highest two deciles (9 and 10). Likewise, there were lower percentages of Decatur employees in the first three deciles and higher percentages in the upper deciles (6-10), in particular decile 9. Because of these disparities, mean BMI values were greater in the
Table 2 Number of employees (\%) by location for reference points of demographic factors and clinical chemistry results
Percentage values are given in parentheses

${ }^{a}$ Chi square test of significance

b See text for description

\begin{tabular}{|c|c|c|c|c|}
\hline & $\begin{array}{l}\text { Antwerp } \\
(N=196)\end{array}$ & $\begin{array}{l}\text { Cottage Grove } \\
(N=122)\end{array}$ & $\begin{array}{l}\text { Decatur } \\
(N=188)\end{array}$ & $\begin{array}{l}P \\
\text { value }^{\mathrm{a}}\end{array}$ \\
\hline Age $<40$ years & $127(65)$ & $57(47)$ & $76(40)$ & 0.0001 \\
\hline $\mathrm{BMI} \geq 30$ & $9(5)$ & $54(44)$ & $61(32)$ & 0.0001 \\
\hline Alcohol $\geq 1$ drink/day & $92(47)$ & $49(40)$ & $2(1)$ & 0.0001 \\
\hline Glucose $\geq 110 \mathrm{mg} / \mathrm{dl}$ & $10(5)$ & $22(18)$ & $16(9)$ & 0.001 \\
\hline Cholesterol $\geq 200 \mathrm{mg} / \mathrm{dl}$ & $119(61)$ & $69(57)$ & $114(61)$ & 0.72 \\
\hline Cholesterol $\geq 240 \mathrm{mg} / \mathrm{dl}$ & $60(31)$ & $32(26)$ & $50(27)$ & 0.60 \\
\hline $\mathrm{HDL}<40 \mathrm{mg} / \mathrm{dl}$ & $16(8)$ & $36(30)$ & $72(38)$ & 0.0001 \\
\hline $\mathrm{LDL} \geq 130 \mathrm{mg} / \mathrm{dl}$ & $106(55)$ & $53(48)$ & $100(55)$ & 0.40 \\
\hline Triglycerides $\geq 150 \mathrm{mg} / \mathrm{dl}$ & $46(23)$ & $58(48)$ & $103(55)$ & 0.0001 \\
\hline Alkaline phosphatase $\geq 120 \mathrm{IU} / \mathrm{l}$ & $0(0)$ & $0(0)$ & $5(3)$ & 0.01 \\
\hline $\mathrm{AST} \geq 40 \mathrm{IU} / 1$ & $4(2)$ & $8(7)$ & $11(6)$ & 0.09 \\
\hline $\mathrm{ALT} \geq 40 \mathrm{IU} / \mathrm{l}$ & $14(7)$ & $34(28)$ & $51(27)$ & 0.0001 \\
\hline GGT $\geq 40 \mathrm{IU} / 1$ & $25(13)$ & $27(22)$ & $34(18)$ & 0.09 \\
\hline Total bilirubin $>1.5 \mathrm{mg} / \mathrm{dl}$ & $13(7)$ & $1(1)$ & $0(0)$ & 0.0001 \\
\hline Direct bilirubin $>0.4 \mathrm{mg} / \mathrm{dl}$ & $0(0)$ & $0(0)$ & $2(1)$ & 0.18 \\
\hline \multicolumn{5}{|l|}{ TSH } \\
\hline$<0.35 \mu \mathrm{IU} / \mathrm{ml}$ & $1(1)$ & $1(1)$ & $1(1)$ & 0.92 \\
\hline$>5.5 \mu \mathrm{IU} / \mathrm{ml}$ & $5(3)$ & $5(4)$ & $8(4)$ & 0.60 \\
\hline \multicolumn{5}{|l|}{ T4 } \\
\hline$<4.5 \mu \mathrm{g} / \mathrm{dl}$ & $1(1)$ & $0(0)$ & $0(0)$ & 0.46 \\
\hline$>12.0 \mu \mathrm{g} / \mathrm{dl}$ & $0(0)$ & $0(0)$ & $0(0)$ & 1.0 \\
\hline \multicolumn{5}{|l|}{ Free T4 } \\
\hline$<0.70 \mathrm{ng} / \mathrm{dl}$ & $1(1)$ & $0(0)$ & $2(1)$ & 0.49 \\
\hline$>1.53 \mathrm{ng} / \mathrm{dl}$ & $3(2)$ & $1(1)$ & $1(1)$ & 0.60 \\
\hline \multicolumn{5}{|l|}{ T3 } \\
\hline$<60 \mathrm{ng} / \mathrm{dl}$ & $0(0)$ & $0(0)$ & $0(0)$ & 1.0 \\
\hline$>181 \mathrm{ng} / \mathrm{dl}$ & $2(1)$ & $3(3)$ & $2(1)$ & 0.46 \\
\hline Metabolic syndrome ${ }^{b}$ & $2(1)$ & $24(20)$ & $25(13)$ & 0.0001 \\
\hline
\end{tabular}


Table 3 Number of employees, arithmetic mean, 95\% confidence interval $(95 \% \mathrm{CI})$, median and range, by PFOA decile

\begin{tabular}{|c|c|c|c|c|c|}
\hline \multicolumn{2}{|l|}{ PFOA } & \multicolumn{4}{|l|}{ PFOA } \\
\hline Decile & $N$ & Mean & $95 \%$ CI & Median & Range \\
\hline 1 & 51 & $0.06^{\mathrm{h}-\mathrm{j}}$ & $0.05-0.07$ & 0.06 & $0.007-0.13$ \\
\hline 2 & 51 & $0.20^{\mathrm{i}, \mathrm{j}}$ & $0.19-0.21$ & 0.19 & $0.13-0.29$ \\
\hline 3 & 51 & $0.36^{\mathrm{i}, \mathrm{j}}$ & $0.35-0.37$ & 0.36 & $0.30-0.44$ \\
\hline 4 & 50 & $0.55^{\mathrm{i}, \mathrm{j}}$ & $0.53-0.57$ & 0.54 & $0.44-0.71$ \\
\hline 5 & 51 & $0.91^{\mathrm{j}}$ & $0.87-0.94$ & 0.91 & $0.72-1.10$ \\
\hline 6 & 49 & $1.26^{\mathrm{j}}$ & $1.23-1.28$ & 1.25 & $1.11-1.40$ \\
\hline 7 & 50 & $1.64^{\mathrm{j}}$ & $1.60-1.67$ & 1.63 & $1.42-1.85$ \\
\hline 8 & 54 & $2.17^{\mathrm{a}, \mathrm{j}}$ & $2.12-2.23$ & 2.18 & $1.86-2.50$ \\
\hline 9 & 49 & $3.00^{\mathrm{a}-\mathrm{d}, \mathrm{j}}$ & $2.90-3.10$ & 2.96 & $2.51-3.69$ \\
\hline 10 & 50 & $12.15^{\mathrm{a}-\mathrm{i}}$ & $7.21-17.10$ & 4.94 & $3.71-92.03$ \\
\hline
\end{tabular}

${ }^{\mathrm{a}-\mathrm{j}}$ Statistically significantly $(P<0.05)$ different than PFOA decile(s) $1,2,3, \ldots, 10$, respectively

upper deciles and alcohol consumption was lower, reflecting the demographic differences seen across the three facilities in Tables 1 and 2 .

Presented in Figs. 1 and 2 are scatterplots of the natural $\operatorname{logs}$ of the blood lipids and PFOA. Pearson correlation coefficients and $P$ values (in parentheses) between PFOA and the lipid parameters were: cholesterol $(r=0.05$, $P=0.32)$, LDL $(r=0.006, P=0.90)$, HDL $(r=-0.17$, $P<0.0001)$, and triglycerides $(r=0.21, P<0.0001)$. Unadjusted and adjusted coefficients for PFOA when regressed with total cholesterol, LDL, HDL, and triglycerides are presented in Table 5. Analyses are also presented for each location in Table 5. PFOA was not a statistically significant coefficient in the regression models for total cholesterol or LDL. In the regression model for HDL that contained all three locations, the adjusted PFOA coefficient was statistically significant $(P=0.01)$ but only explained $1 \%$ of the variance in the model. Separate models analyzed for each of the three locations showed no statistically significant findings between PFOA and HDL. The model for triglycerides for the combined three locations indicated a statistically significant positive coefficient $(P<0.0001)$ for PFOA which explained approximately $4 \%$ of the variance of the response variable. Stratified by location showed Antwerp with a statistically significant positive PFOA coefficient $(P<0.0004)$ and Decatur had a marginally positive coefficient for PFOA $(P=0.07)$. No statistically significant coefficient for PFOA $(P=0.38)$ was found with triglycerides for the Cottage Grove location.

Presented in Table 6 are the mean and 95\% confidence intervals (CI) values for cholesterol, LDL, HDL, and triglycerides by PFOA deciles, adjusted for age, BMI, and alcohol. Mean serum triglyceride levels were highest in the upper three PFOA deciles.

Table 7 presents adjusted odds ratios and 95\% confidence intervals by reference range cutoff points listed in Table 2, using the lowest PFOA decile as the reference. Serum PFOA concentrations were not associated, positively or negatively, with cholesterol or LDL. For $\mathrm{HDL}<40 \mathrm{mg} / \mathrm{dl}$, the non-adjusted odds ratio for the highest decile was 3.0 (95\% CI 1.2-7.5). Adjusted for age, BMI and alcohol, the highest decile odds ratio became 2.6 (95\% CI 1.0-6.8) (Table 5). Adjusted also for location, this odds ratio became 1.8 (95\% CI 0.7-4.8). Adjusted odds ratios for triglyceride levels $\geq 150 \mathrm{mg} / \mathrm{dl}$ were also highest

Table 4 Distribution of demographic factors by PFOA decile

\begin{tabular}{|c|c|c|c|c|c|c|c|c|c|c|c|}
\hline \multirow{2}{*}{$\begin{array}{l}\text { PFOA } \\
\text { Decile }\end{array}$} & \multirow{2}{*}{$\begin{array}{l}\text { Antwerp } \\
N(\%)\end{array}$} & \multirow{2}{*}{$\begin{array}{l}\text { Cottage Grove } \\
N(\%)\end{array}$} & \multirow{2}{*}{$\begin{array}{l}\text { Decatur } \\
N(\%)\end{array}$} & \multicolumn{2}{|l|}{ Age } & \multicolumn{2}{|l|}{ BMI } & \multirow{2}{*}{$\begin{array}{l}\mathrm{BMI} \geq 30 \\
N(\%)\end{array}$} & \multicolumn{2}{|c|}{ Drinks/day } & \multirow{2}{*}{$\begin{array}{l}\geq 1 \text { drink/day } \\
N(\%)\end{array}$} \\
\hline & & & & Mean & (SD) & Mean & (SD) & & Mean & (SD) & \\
\hline 1 & $28(55)$ & 17 (33) & $6(12)$ & 39 & (11) & 27.1 & (4.8) & $13(25)$ & 0.7 & $(0.7)^{\mathrm{i}}$ & $21(41)$ \\
\hline 2 & 25 (49) & $13(26)$ & $13(25)$ & 41 & (9) & 26.7 & $(4.1)^{\mathrm{i}}$ & 7 (14) & 0.7 & $(0.9)^{\mathrm{i}}$ & 17 (33) \\
\hline 3 & $28(55)$ & $11(22)$ & $12(23)$ & 38 & (8) & 26.4 & $(3.9)^{\mathrm{i}, \mathrm{j}}$ & $8(16)$ & 0.7 & $(1.0)^{\mathrm{i}}$ & 15 (29) \\
\hline 4 & $20(40)$ & 13 (26) & $17(34)$ & 38 & (10) & 27.8 & $(4.3)$ & $13(26)$ & 0.7 & $(1.0)^{\mathrm{i}}$ & $13(26)$ \\
\hline 5 & $22(43)$ & $11(22)$ & $18(35)$ & 40 & (10) & 27.2 & (5.0) & $8(17)$ & 0.7 & $(1.0)^{\mathrm{i}}$ & $16(32)$ \\
\hline 6 & $21(43)$ & 7 (14) & $21(43)$ & 40 & (9) & 27.4 & $(4.8)$ & $12(24)$ & 0.7 & $(1.0)^{\mathrm{i}}$ & $14(29)$ \\
\hline 7 & $20(40)$ & $9(18)$ & $21(42)$ & 39 & (9) & 26.9 & $(3.9)^{\mathrm{i}}$ & $10(20)$ & 0.7 & $(0.9)^{\mathrm{i}}$ & $14(28)$ \\
\hline 8 & 18 (33) & $11(20)$ & $25(46)$ & 41 & (10) & 27.5 & $(5.4)$ & $17(31)$ & 0.6 & $(0.9)^{\mathrm{i}}$ & $16(30)$ \\
\hline 9 & $9(18)$ & 7 (14) & $33(67)$ & 39 & (9) & 28.9 & $(4.9)^{\mathrm{b}, \mathrm{c}, \mathrm{g}}$ & $21(43)$ & 0.3 & $(0.5)^{\mathrm{a}-\mathrm{h}}$ & $5(10)$ \\
\hline \multirow[t]{2}{*}{10} & $5(10)$ & $23(46)$ & $22(44)$ & 39 & (9) & 28.3 & $(4.0)^{\mathrm{c}}$ & $15(30)$ & 0.5 & $(0.7)$ & $12(24)$ \\
\hline & & $P<0.0001^{\mathrm{k}}$ & & & & & & $P<0.03^{1}$ & & & $P<0.14^{\mathrm{m}}$ \\
\hline
\end{tabular}

${ }^{\mathrm{a}-\mathrm{j}}$ Statistically significantly $(P<0.05)$ different than PFOA decile $1,2,3, \ldots, 10$, respectively

k, 1, m $P$ value associated with Chi square test for location, BMI distribution and $\geq 1$ drink/day, respectively 

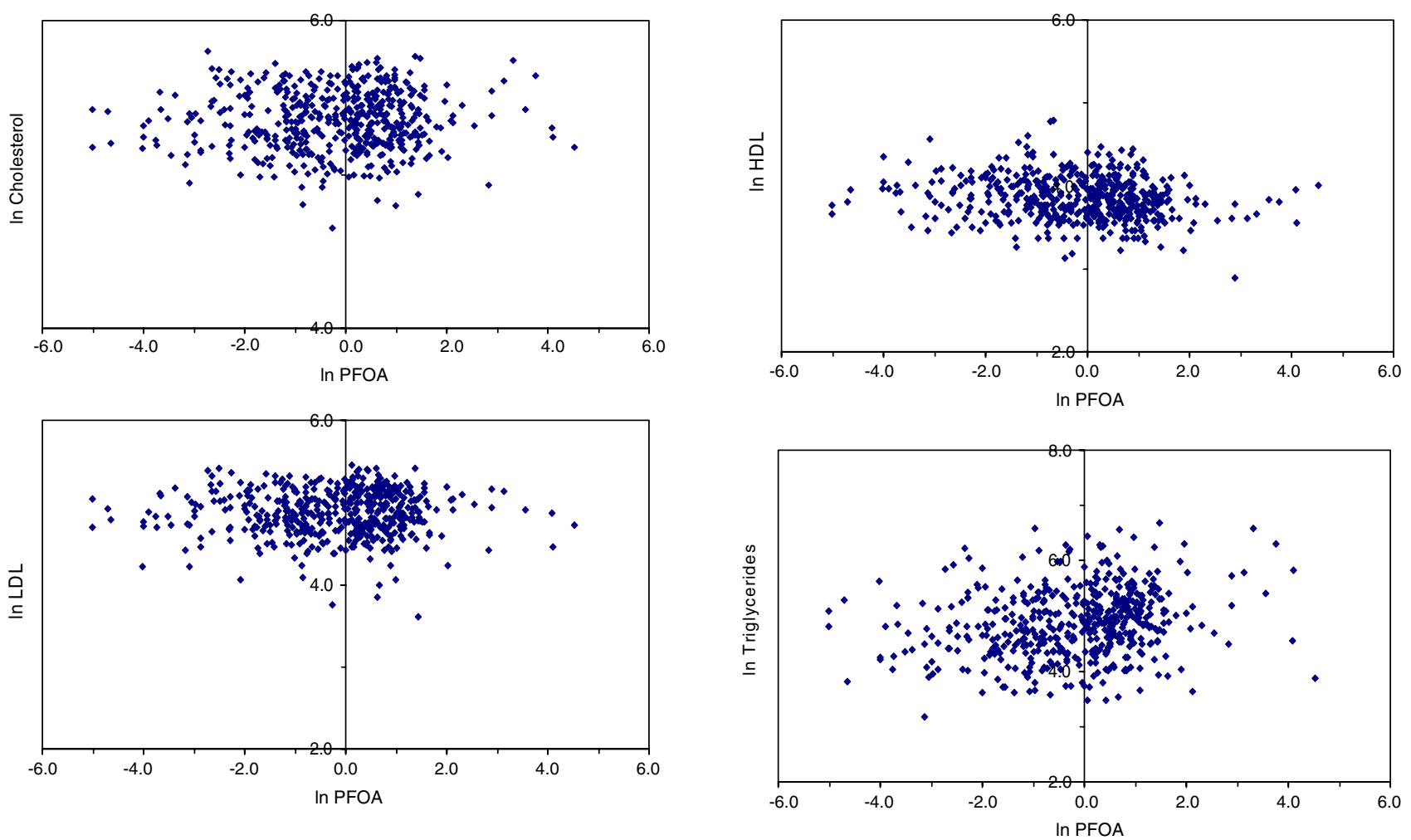

Fig. 1 Scatterplots of the natural $\log$ PFOA (ng/ml) by the natural $\log$ total cholesterol and LDL

for PFOA deciles $8-10$ as seen with adjusted mean triglyceride values reported in Table 7.

Presented in Figs. 3 and 4 are scatterplots of natural logs of hepatic clinical chemistries by PFOA. Pearson correlation coefficients and $P$ values (in parentheses) between PFOA and the hepatic parameters were: alkaline phosphatase $(r=0.08, P=0.06)$, AST $(r=-0.01 P=0.83)$, ALT $\quad(r=0.005, \quad P<0.005), \quad$ and GGT $(r=0.02$, $P<0.02)$. Analyses presented in Table 8 of the regression models showed marginal statistically significant coefficients for PFOA when adjusted for age, BMI, and alcohol for $\operatorname{ALT}(P=0.06)$ and GGT $(P=0.05)$ but not when adjusted for age, triglycerides, and alcohol for ALT $(P=0.40)$ and GGT $(P=0.55)$. Total bilirubin was statistically significantly negatively associated with PFOA regardless of covariates used. Stratified by location, Decatur had marginally statistically significant positive coefficients, regardless of covariates adjusted, ranging between $0.01<P<0.07$ for alkaline phosphatase, ALT, GGT, and total bilirubin. The amount of variance of the hepatic response variables explained by PFOA in these models was minimal ranging from $<1$ to $3 \%$. No statistically significant PFOA coefficients for the hepatic enzymes were observed in either the Antwerp or Cottage Grove regression models.

Fig. 2 Scatterplots of the natural $\log$ PFOA $(\mathrm{ng} / \mathrm{ml})$ by the natural $\log$ HDL and triglycerides

No discernable trends in adjusted mean hepatic enzyme values were apparent when analyzed by deciles (Table 9). There were no statistically significant odds ratios (nonadjusted or adjusted) for the reference points AL$\mathrm{T} \geq 40 \mathrm{IU} / 1$ or GGT $\geq 40 \mathrm{IU} / 1$ when compared to decile 1 (Table 10). Odds ratios for alkaline phosphatase, AST, and total bilirubin are not shown because of the failure of the logistic models to converge because of the very few data points that were out-of-reference range (Table 2) for these clinical parameters.

Presented in Figs. 5 and 6 are scatterplots of natural logs of thyroid hormones by PFOA. Pearson correlation coefficients and $P$ values (in parentheses) between PFOA and the thyroid hormones were: TSH $(r=0.08, P=0.07)$, T4 $(r=-0.04, P=0.32)$, free T4 $(r=-0.14, P<0.002)$, and T3 $(r=0.07, P=0.11)$. For all locations combined, there were no statistically significant adjusted coefficients for PFOA in the models except for Free T4 (negative coefficient for PFOA) and T3 (positive coefficient for PFOA) (Table 11). However, the full models only explained 5 and $2 \%$ of the variance of free $\mathrm{T} 4$ and $\mathrm{T} 3$, respectively. The thyroid results were considered not clinically relevant as results from these models were well within normal reference ranges for the four thyroid parameters when serum PFOA concentrations were predicted in a model to range 
Table 5 Non-adjusted and adjusted natural $\log (\ln )$ PFOA coefficients with $\ln$ lipid measurements a See study methods. Adjusted for Ln age, Ln BMI, Ln alcohol

\begin{tabular}{|c|c|c|c|c|c|c|}
\hline & \multicolumn{3}{|c|}{$\begin{array}{l}\text { Ln PFOA } \\
\text { Non-adjusted }\end{array}$} & \multicolumn{3}{|l|}{$\begin{array}{l}\text { Ln PFOA } \\
\text { Adjusted }^{\mathrm{a}}\end{array}$} \\
\hline & Coefficient & SE & $P$ value & Coefficient & SE & $P$ value \\
\hline \multicolumn{7}{|l|}{ Ln cholesterol } \\
\hline All locations & 0.0059 & 0.0060 & 0.32 & 0.0076 & 0.0059 & 0.20 \\
\hline Antwerp & 0.0051 & 0.0106 & 0.63 & 0.0130 & 0.0096 & 0.18 \\
\hline Cottage Grove & 0.0034 & 0.0089 & 0.70 & 0.0021 & 0.0100 & 0.83 \\
\hline Decatur & 0.0221 & 0.0139 & 0.11 & 0.0266 & 0.0141 & 0.06 \\
\hline \multicolumn{7}{|l|}{ Ln LDL } \\
\hline All locations & 0.0012 & 0.0089 & 0.89 & 0.0021 & 0.0090 & 0.81 \\
\hline Antwerp & -0.0037 & 0.0157 & 0.81 & 0.0106 & 0.0147 & 0.47 \\
\hline Cottage Grove & -0.0022 & 0.0139 & 0.87 & 0.0049 & 0.0145 & 0.73 \\
\hline Decatur & 0.0258 & 0.0199 & 0.20 & 0.0302 & 0.0200 & 0.13 \\
\hline \multicolumn{7}{|l|}{ Ln HDL } \\
\hline All locations & -0.0307 & 0.0079 & 0.0001 & -0.0183 & 0.0069 & 0.01 \\
\hline Antwerp & -0.0057 & 0.0136 & 0.68 & -0.0095 & 0.0131 & 0.47 \\
\hline Cottage Grove & -0.0153 & 0.0122 & 0.21 & -0.0192 & 0.0120 & 0.11 \\
\hline Decatur & -0.0256 & 0.0149 & 0.09 & -0.0207 & 0.0141 & 0.14 \\
\hline \multicolumn{7}{|l|}{ Ln triglycerides } \\
\hline All locations & 0.0892 & 0.0185 & 0.0001 & 0.0711 & 0.0169 & 0.0001 \\
\hline Antwerp & 0.0840 & 0.0288 & 0.004 & 0.0980 & 0.0270 & 0.0004 \\
\hline Cottage Grove & 0.0343 & 0.0316 & 0.28 & 0.0280 & 0.0314 & 0.38 \\
\hline Decatur & 0.0715 & 0.0400 & 0.08 & 0.0689 & 0.0376 & 0.07 \\
\hline
\end{tabular}

between 0.005 and $100 \mu \mathrm{g} / \mathrm{ml}$ (Table 12). Presented in Table 13 are the mean thyroid hormone-related values adjusted for age, BMI and alcohol. The mean TSH value in the fourth decile of Table 13 is influenced by one subject whose TSH value was $65.3 \mu \mathrm{IU} / \mathrm{ml}$ (see overall results in Table 1) who was not diagnosed at the time as hypothyroid. If removed, the mean of the fourth decile became $2.15 \mu \mathrm{IU} / \mathrm{ml}$ and the decile statistically significant differences with this fourth decile in Table 13 disappear. The adjusted mean for the highest decile for free $\mathrm{T} 4$ was statistically significantly lower than that of the first decile. There were no statistically significant differences between decile-adjusted means for T3 in Table 13. Because so few thyroid values were out-of-reference range (Table 2), the findings from the logistic analyses are not presented because of the models' lack of convergence.

PFOA was not associated with the metabolic syndrome. Age-adjusted odds ratios (95\% CI in parentheses) for the

Table 6 Adjusted mean and 95\% confidence intervals (95\% CI) for lipid clinical chemistry results, by PFOA decile

\begin{tabular}{|c|c|c|c|c|c|c|c|c|}
\hline \multirow{2}{*}{$\begin{array}{l}\text { PFOA } \\
\text { Decile }\end{array}$} & \multicolumn{2}{|c|}{ Cholesterol } & \multicolumn{2}{|l|}{ LDL } & \multicolumn{2}{|l|}{ HDL } & \multicolumn{2}{|c|}{ Triglycerides } \\
\hline & Mean & $95 \% \mathrm{CI}$ & Mean & $95 \% \mathrm{CI}$ & Mean & $95 \% \mathrm{CI}$ & Mean & $95 \% \mathrm{CI}$ \\
\hline 1 & 214 & $203-225$ & 137 & $127-147$ & $50^{\mathrm{j}}$ & $46-53$ & $145^{\mathrm{j}}$ & $116-173$ \\
\hline 2 & 211 & $199-222$ & 135 & $125-145$ & $51^{\mathrm{j}}$ & $48-54$ & $124^{\mathrm{h}-\mathrm{j}}$ & $95-153$ \\
\hline 3 & 209 & $198-220$ & 128 & $118-138$ & $51^{\mathrm{j}}$ & $48-54$ & $153^{\mathrm{j}}$ & $124-182$ \\
\hline 4 & 210 & $199-222$ & 133 & $123-143$ & $50^{\mathrm{j}}$ & $46-53$ & $145^{\mathrm{j}}$ & $116-175$ \\
\hline 5 & 217 & $206-228$ & 140 & $130-150$ & 48 & $45-51$ & $162^{\mathrm{j}}$ & $133-191$ \\
\hline 6 & 218 & $206-229$ & 141 & $130-151$ & 48 & $45-51$ & $160^{\mathrm{j}}$ & $131-190$ \\
\hline 7 & 214 & $203-225$ & 133 & $123-143$ & $50^{\mathrm{j}}$ & $47-53$ & $158^{\mathrm{j}}$ & $128-187$ \\
\hline 8 & 215 & $204-226$ & 136 & $126-146$ & 47 & $44-50$ & 172 & 144-201 \\
\hline 9 & 221 & $210-233$ & 140 & $130-150$ & 48 & $44-52$ & $165^{\mathrm{j}}$ & 135-194 \\
\hline 10 & 216 & $204-227$ & 133 & $123-144$ & $44^{\mathrm{a}-\mathrm{d}}$ & $41-47$ & $208^{\mathrm{a}-\mathrm{g}, \mathrm{i}}$ & $179-238$ \\
\hline
\end{tabular}

Adjusted for age, BMI and alcohol

${ }^{\mathrm{a}-\mathrm{j}}$ Statistically significantly $(P<0.05)$ different than PFOA decile(s) $1,2,3, \ldots, 10$, respectively 
Table 7 Adjusted odds ratios (OR) and 95\% confidence intervals (95\% CI) for lipid clinical chemistry reference points, by PFOA decile

\begin{tabular}{|c|c|c|c|c|c|c|c|c|c|c|c|c|c|c|c|c|}
\hline \multirow{2}{*}{$\begin{array}{l}\text { PFOA } \\
\text { Decile }\end{array}$} & \multicolumn{4}{|c|}{ Chol $\geq 200 \mathrm{mg} / \mathrm{dl}$} & \multicolumn{4}{|c|}{$\mathrm{LDL} \geq 130 \mathrm{mg} / \mathrm{dl}$} & \multicolumn{4}{|c|}{$\mathrm{HDL} \leq 40 \mathrm{mg} / \mathrm{dl}$} & \multicolumn{4}{|c|}{ Triglycerides $\geq 150 \mathrm{mg} / \mathrm{dl}$} \\
\hline & $\mathrm{OR}^{\mathrm{a}}$ & $95 \% \mathrm{CI}$ & $\mathrm{OR}^{\mathrm{b}}$ & $95 \% \mathrm{CI}$ & $\mathrm{OR}^{\mathrm{a}}$ & $95 \% \mathrm{CI}$ & $\mathrm{OR}^{\mathrm{b}}$ & $95 \% \mathrm{CI}$ & $\mathrm{OR}^{\mathrm{a}}$ & $95 \% \mathrm{CI}$ & $\mathrm{OR}^{\mathrm{b}}$ & $95 \% \mathrm{CI}$ & $\mathrm{OR}^{\mathrm{a}}$ & $95 \% \mathrm{CI}$ & $\mathrm{OR}^{\mathrm{b}}$ & $95 \% \mathrm{CI}$ \\
\hline 1 & 1.0 & - & 1.0 & - & 1.0 & - & 1.0 & - & 1.0 & - & 1.0 & - & 1.0 & - & 1.0 & - \\
\hline 2 & 0.4 & $0.2-1.0$ & 0.4 & $0.2-1.0$ & 0.7 & $0.3-1.6$ & 0.7 & $0.3-1.7$ & 1.1 & $0.4-3.2$ & 1.0 & $0.4-3.0$ & 0.7 & $0.3-1.8$ & 0.6 & $0.2-1.6$ \\
\hline 3 & 0.9 & $0.4-2.0$ & 0.9 & $0.4-2.0$ & 0.7 & $0.3-1.6$ & 0.7 & $0.3-1.6$ & 0.5 & $0.1-1.5$ & 0.4 & $0.1-1.3$ & 1.0 & $0.4-2.4$ & 0.9 & $0.4-2.2$ \\
\hline 4 & 0.9 & $0.4-2.1$ & 0.9 & $0.4-2.0$ & 0.8 & $0.4-1.8$ & 0.8 & $0.4-1.9$ & 2.0 & $0.8-5.4$ & 1.7 & $0.6-4.7$ & 1.3 & $0.5-3.1$ & 1.1 & $0.4-2.6$ \\
\hline 5 & 1.7 & $0.7-4.0$ & 1.6 & $0.7-3.9$ & 1.4 & $0.6-3.1$ & 0.4 & $0.6-3.2$ & 1.0 & $0.4-2.9$ & 0.8 & $0.3-2.4$ & 1.2 & $0.5-3.0$ & 1.0 & $0.4-2.5$ \\
\hline 6 & 1.0 & $0.4-2.2$ & 0.9 & $0.4-2.1$ & 0.9 & $0.4-2.0$ & 0.9 & $0.4-2.1$ & 1.7 & $0.7-4.7$ & 1.4 & $0.5-3.9$ & 1.7 & $0.7-4.0$ & 1.3 & $0.5-3.2$ \\
\hline 7 & 0.8 & $0.4-1.9$ & 0.8 & $0.3-1.8$ & 0.7 & $0.3-1.5$ & 0.7 & $0.4-1.6$ & 0.6 & $0.2-1.8$ & 0.5 & $0.1-1.4$ & 0.9 & $0.4-2.2$ & 0.7 & $0.3-1.8$ \\
\hline 8 & 1.0 & $0.4-2.2$ & 0.9 & $0.4-2.1$ & 1.1 & $0.5-2.4$ & 1.1 & $0.5-2.5$ & 1.4 & $0.5-3.7$ & 1.0 & $0.4-2.8$ & 2.7 & $1.2-6.5$ & 2.1 & $0.9-5.2$ \\
\hline 9 & 1.4 & $0.6-3.3$ & 1.3 & $0.6-3.1$ & 1.2 & $0.5-2.7$ & 1.2 & $0.5-2.8$ & 0.9 & $0.3-2.4$ & 0.6 & $0.2-1.7$ & 2.4 & $1.0-5.9$ & 1.7 & $0.7-4.3$ \\
\hline 10 & 1.1 & $0.5-2.6$ & 1.1 & $0.5-2.6$ & 1.2 & $0.5-2.8$ & 1.4 & $0.6-3.3$ & 2.6 & $1.0-6.8$ & 1.8 & $0.7-4.8$ & 2.4 & $1.0-5.8$ & 1.8 & $0.8-4.4$ \\
\hline
\end{tabular}

a Adjusted for age, BMI and alcohol

b Adjusted for age, BMI, alcohol and location

6th, 7th, 8th, 9th and 10th PFOA deciles were $1.0(0.3-$ $3.5), 0.5$ (0.1-2.0), $0.9(0.3-3.0), 1.1(0.3-3.6)$ and 1.0 (0.3-3.6), respectively.

Other analyses included those subjects $(n=46)$ who self-reported cholesterol lowering medication usage. These 46 subjects, compared to the 506 non-prescribed subjects, had comparable mean PFOA concentrations $(1.98 \mu \mathrm{g} / \mathrm{ml}$
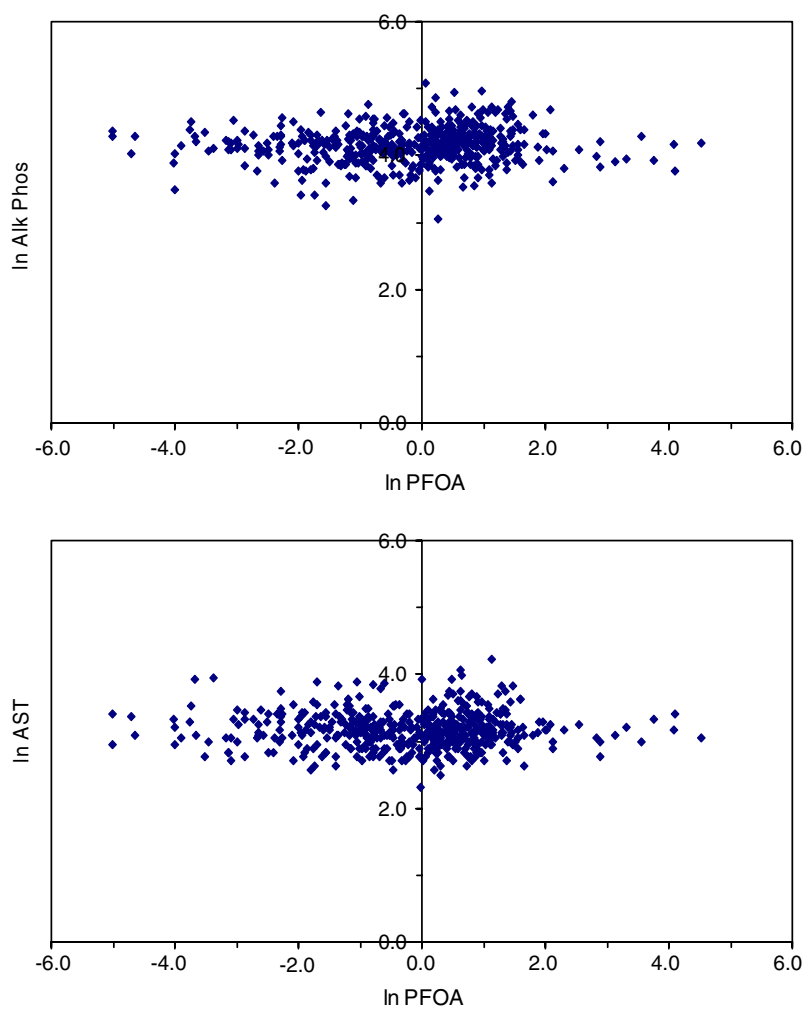

Fig. 3 Scatterplots of the natural $\log$ PFOA $(\mathrm{ng} / \mathrm{ml})$ by the natural log alkaline phosphatase and AST vs. $2.21 \mu \mathrm{g} / \mathrm{ml}$ ) but were statistically significantly older (49 vs. 40) and had higher mean BMI (28.8 vs. 27.4), serum glucose (103 vs. 91), triglycerides (226 vs. 159), and several liver enzyme results (alkaline phosphatase 73 vs. 66, ALT 36 vs. 30, GGT 36 vs. 28). Cholesterol (221 vs. 214), LDL (134 vs. 136), and HDL (47 vs. 49) were not statistically significantly different between the two groups. No
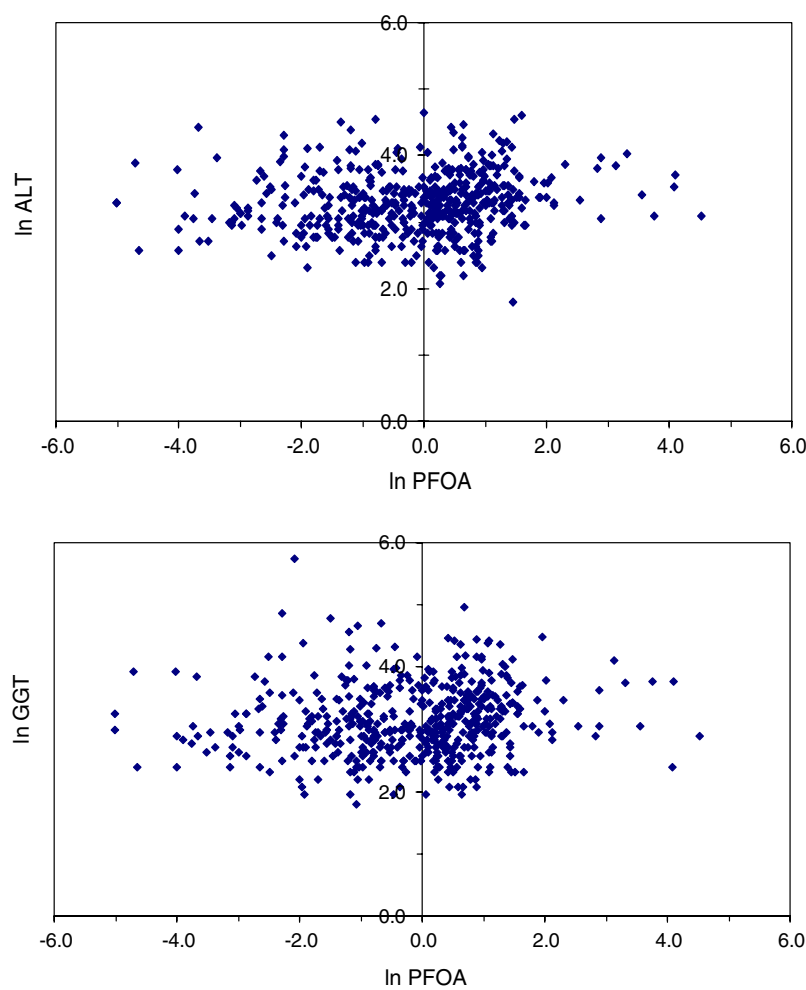

Fig. 4 Scatterplots of the natural $\log$ PFOA (ng/ml) by the natural $\log$ ALT and GGT 
Table 8 Non-adjusted and adjusted natural $\log (\ln )$ PFOA coefficients with $\ln$ hepatic clinical chemistry measurements

\begin{tabular}{|c|c|c|c|c|c|c|}
\hline & \multicolumn{3}{|c|}{$\begin{array}{l}\text { Non-adjusted } \\
\text { Ln PFOA }\end{array}$} & \multicolumn{3}{|l|}{$\begin{array}{l}\text { Adjusted }^{\text {a, b }} \\
\text { Ln PFOA }\end{array}$} \\
\hline & Coefficient & SE & $P$ value & Coefficient & SE & $P$ value \\
\hline \multicolumn{7}{|c|}{ Ln alkaline phosphatase } \\
\hline All locations & 0.0155 & 0.0082 & 0.06 & $\begin{array}{l}0.0093^{\mathrm{a}} \\
0.0037^{\mathrm{b}}\end{array}$ & $\begin{array}{l}0.0081 \\
0.0081\end{array}$ & $\begin{array}{l}0.25 \\
0.65\end{array}$ \\
\hline Antwerp & -0.0025 & 0.0137 & 0.85 & $\begin{array}{l}-0.0060 \\
-0.0170\end{array}$ & $\begin{array}{l}0.0139 \\
0.0140\end{array}$ & $\begin{array}{l}0.67 \\
0.22\end{array}$ \\
\hline Cottage Grove & -0.0141 & 0.0113 & 0.21 & $\begin{array}{l}-0.0127 \\
-0.0140\end{array}$ & $\begin{array}{l}0.0117 \\
0.0117\end{array}$ & $\begin{array}{l}0.28 \\
0.24\end{array}$ \\
\hline Decatur & 0.0394 & 0.0191 & 0.04 & $\begin{array}{l}0.0460 \\
0.0394\end{array}$ & $\begin{array}{l}0.0192 \\
0.0192\end{array}$ & $\begin{array}{l}0.02 \\
0.04\end{array}$ \\
\hline \multicolumn{7}{|l|}{ Ln AST } \\
\hline All locations & -0.0018 & 0.0086 & 0.83 & $\begin{array}{r}-0.0051 \\
-0.0089\end{array}$ & $\begin{array}{l}0.0086 \\
0.0087\end{array}$ & $\begin{array}{l}0.55 \\
0.31\end{array}$ \\
\hline Antwerp & -0.0048 & 0.0137 & 0.73 & $\begin{array}{l}-0.0029 \\
-0.0066\end{array}$ & $\begin{array}{l}0.0138 \\
0.0142\end{array}$ & $\begin{array}{l}0.83 \\
0.64\end{array}$ \\
\hline Cottage Grove & -0.0281 & 0.0141 & 0.05 & $\begin{array}{l}-0.0258 \\
-0.0271\end{array}$ & $\begin{array}{l}0.0146 \\
0.0145\end{array}$ & $\begin{array}{l}0.08 \\
0.07\end{array}$ \\
\hline Decatur & 0.0205 & 0.0200 & 0.31 & $\begin{array}{l}0.0114 \\
0.0062\end{array}$ & $\begin{array}{l}0.0203 \\
0.0203\end{array}$ & $\begin{array}{l}0.57 \\
0.76\end{array}$ \\
\hline \multicolumn{7}{|l|}{ Ln ALT } \\
\hline All locations & 0.0402 & 0.0143 & 0.005 & $\begin{array}{l}0.0249 \\
0.0115\end{array}$ & $\begin{array}{l}0.0132 \\
0.0136\end{array}$ & $\begin{array}{l}0.06 \\
0.40\end{array}$ \\
\hline Antwerp & -0.0122 & 0.0220 & 0.58 & $\begin{array}{l}-0.0085 \\
-0.0293\end{array}$ & $\begin{array}{l}0.0222 \\
0.0222\end{array}$ & $\begin{array}{l}0.70 \\
0.19\end{array}$ \\
\hline Cottage Grove & -0.0131 & 0.0215 & 0.54 & $\begin{array}{l}-0.0096 \\
-0.0008\end{array}$ & $\begin{array}{l}0.0209 \\
0.0208\end{array}$ & $\begin{array}{l}0.65 \\
0.69\end{array}$ \\
\hline Decatur & 0.0954 & 0.0300 & 0.002 & $\begin{array}{l}0.0704 \\
0.0581\end{array}$ & $\begin{array}{l}0.0287 \\
0.0287\end{array}$ & $\begin{array}{l}0.02 \\
0.04\end{array}$ \\
\hline \multicolumn{7}{|l|}{ Ln GGT } \\
\hline All locations & 0.0409 & 0.0174 & 0.02 & $\begin{array}{l}0.0326 \\
0.0097\end{array}$ & $\begin{array}{l}0.0166 \\
0.0163\end{array}$ & $\begin{array}{l}0.05 \\
0.55\end{array}$ \\
\hline Antwerp & 0.0170 & 0.0307 & 0.58 & $\begin{array}{r}0.0269 \\
-0.0047\end{array}$ & $\begin{array}{l}0.0294 \\
0.0295\end{array}$ & $\begin{array}{l}0.36 \\
0.87\end{array}$ \\
\hline Cottage Grove & -0.0088 & 0.0292 & 0.76 & $\begin{array}{l}-0.0198 \\
-0.0233\end{array}$ & $\begin{array}{l}0.0286 \\
0.0270\end{array}$ & $\begin{array}{l}0.49 \\
0.39\end{array}$ \\
\hline Decatur & 0.0754 & 0.0344 & 0.03 & $\begin{array}{l}0.0800 \\
0.0599\end{array}$ & $\begin{array}{l}0.0344 \\
0.0329\end{array}$ & $\begin{array}{l}0.02 \\
0.07\end{array}$ \\
\hline \multicolumn{7}{|l|}{ Ln total bilirubin } \\
\hline All locations & -0.0406 & 0.0101 & 0.0001 & $\begin{array}{l}-0.0325 \\
-0.0267\end{array}$ & $\begin{array}{l}0.0099 \\
0.0101\end{array}$ & $\begin{array}{l}0.001 \\
0.01\end{array}$ \\
\hline Antwerp & -0.0117 & 0.0178 & 0.51 & $\begin{array}{l}-0.0122 \\
-0.0093\end{array}$ & $\begin{array}{l}0.0182 \\
0.0188\end{array}$ & $\begin{array}{l}0.50 \\
0.62\end{array}$ \\
\hline Cottage Grove & -0.0060 & 0.0138 & 0.66 & $\begin{array}{l}-0.0098 \\
-0.0067\end{array}$ & $\begin{array}{l}0.0142 \\
0.0141\end{array}$ & $\begin{array}{l}0.49 \\
0.64\end{array}$ \\
\hline Decatur & -0.0528 & 0.0203 & 0.01 & $\begin{array}{l}-0.0537 \\
-0.0462\end{array}$ & $\begin{array}{l}0.0209 \\
0.0206\end{array}$ & $\begin{array}{l}0.01 \\
0.03\end{array}$ \\
\hline
\end{tabular}

a Study methods. Adjusted for Ln age, Ln BMI, Ln alcohol

b Study methods. Adjusted for Ln age, Ln triglycerides, Ln alcohol 
Table 9 Adjusted mean and 95\% confidence intervals (95\% CI) for hepatic clinical chemistry results, by PFOA decile

\begin{tabular}{|c|c|c|c|c|c|c|c|c|c|c|c|c|}
\hline \multirow{3}{*}{$\begin{array}{l}\text { PFOA } \\
\text { Decile }\end{array}$} & \multirow{2}{*}{\multicolumn{2}{|c|}{ Alk Phos }} & \multirow{2}{*}{\multicolumn{2}{|c|}{ AST }} & & & & & \multirow{2}{*}{\multicolumn{2}{|c|}{ Bilirubin }} & \multirow{2}{*}{\multicolumn{2}{|c|}{$\frac{\text { Direct }}{\text { Bilirubin }}$}} \\
\hline & & & & & \multicolumn{2}{|l|}{ ALT } & \multicolumn{2}{|l|}{ GGT } & & & & \\
\hline & Mean & $95 \% \mathrm{CI}$ & Mean & $95 \% \mathrm{CI}$ & Mean & $95 \% \mathrm{CI}$ & Mean & $95 \% \mathrm{CI}$ & Mean & $95 \%$ CI & Mean & $95 \% \mathrm{CI}$ \\
\hline 1 & 66 & $61-71$ & $26^{\mathrm{e}, \mathrm{f}}$ & $24-28$ & 29 & $25-33$ & $32^{f}$ & $27-38$ & $0.9^{\mathrm{i}}$ & $0.86-1.02$ & 0.1 & $0.09-0.12$ \\
\hline 2 & $59^{\mathrm{g}, \mathrm{i}, \mathrm{j}}$ & $54-64$ & 25 & $23-27$ & 29 & $25-33$ & 25 & $19-31$ & $0.9^{\mathrm{i}}$ & $0.84-1.00$ & 0.1 & $0.09-0.12$ \\
\hline 3 & $64^{\mathrm{g}}$ & $59-69$ & $26^{\mathrm{e}, \mathrm{f}}$ & $24-28$ & 30 & $26-34$ & 27 & $21-33$ & $1.0^{\mathrm{f}-\mathrm{j}}$ & 0.89-1.06 & 0.1 & $0.09-0.12$ \\
\hline 4 & 65 & $61-70$ & 24 & $22-26$ & $28^{\mathrm{i}, \mathrm{j}}$ & $24-32$ & 28 & $22-34$ & $0.9^{\mathrm{i}}$ & $0.82-0.99$ & 0.1 & $0.08-0.11$ \\
\hline 5 & $64^{\mathrm{g}}$ & $60-69$ & $22^{\mathrm{a}, \mathrm{c}, \mathrm{g}-\mathrm{i}}$ & $20-25$ & $27^{\mathrm{i}, \mathrm{j}}$ & $23-31$ & $24^{\mathrm{i}}$ & $18-30$ & 0.9 & $0.79-0.95$ & $0.1^{\mathrm{i}}$ & $0.10-0.13$ \\
\hline 6 & 66 & $61-71$ & $22^{\mathrm{a}, \mathrm{c}, \mathrm{g}-\mathrm{i}}$ & $20-24$ & $25^{\mathrm{g}, \mathrm{i}, \mathrm{j}}$ & $21-28$ & $21^{\mathrm{a}, \mathrm{i}}$ & $15-27$ & $0.9^{c}$ & $0.78-0.95$ & 0.1 & $0.08-0.11$ \\
\hline 7 & $72^{\mathrm{b}, \mathrm{c}, \mathrm{e}, \mathrm{h}}$ & $67-77$ & $26^{\mathrm{e}, \mathrm{f}}$ & $24-28$ & $31^{\mathrm{f}}$ & $27-35$ & 28 & $22-34$ & $0.9^{\mathrm{c}}$ & $0.77-0.94$ & 0.1 & $0.08-0.11$ \\
\hline 8 & $65^{\mathrm{g}}$ & $60-70$ & $26^{\mathrm{e}, \mathrm{f}}$ & $24-28$ & 29 & $26-33$ & 29 & $23-35$ & $0.9^{\mathrm{c}}$ & $0.77-0.93$ & $0.1^{\mathrm{i}}$ & $0.10-0.13$ \\
\hline 9 & $70^{\mathrm{b}}$ & $66-75$ & $26^{\mathrm{e}, \mathrm{f}}$ & $24-28$ & $34^{\mathrm{d}-\mathrm{f}}$ & $30-38$ & $33^{\mathrm{e}, \mathrm{f}}$ & $27-39$ & $0.8^{\mathrm{a}-\mathrm{d}}$ & $0.69-0.85$ & $0.1^{\mathrm{e}, \mathrm{h}}$ & $0.07-0.10$ \\
\hline 10 & $68^{\mathrm{b}}$ & $63-72$ & 24 & $22-26$ & $34^{\mathrm{d}-\mathrm{f}}$ & $30-38$ & 30 & $24-36$ & $0.8^{\mathrm{c}}$ & $0.75-0.92$ & 0.1 & $0.08-0.12$ \\
\hline
\end{tabular}

Adjusted for age, BMI, and alcohol

${ }^{\mathrm{a}-\mathrm{j}}$ Statistically significantly $(P<0.05)$ different than PFOA decile(s) $1,2,3, \ldots, 10$, respectively

significant differences were observed with thyroid hormones. Twenty percent of these 46 subjects were categorized as having the metabolic syndrome compared to $7 \%$ of those not prescribed cholesterol-lowering medication. Not unexpectedly based on the results already presented, a greater percentage of those prescribed cholesterol-lowering medications were Cottage Grove and Decatur employees (79\%) than those not prescribed medications (61\%). Analyses with the clinical chemistries were similar whether they excluded or included these 46 employees who selfreported cholesterol lowering medications (data not shown).

\section{Discussion}

Based on an analysis of 506 male participants of the 2000 fluorochemical medical surveillance program offered at the 3M Antwerp, Cottage Grove, and Decatur fluorochemical production facilities who self-reported that they did not take cholesterol lowering medications, there was no evidence that these employees' serum PFOA concentrations were positively, or negatively, associated with serum total cholesterol or LDL. These data analyses support the argument that the PFOA and cholesterol association observed in an analysis by Olsen et al. (2003a) of Antwerp and Decatur workers in this database could have been a spurious finding or may have been the result of residual confounding between the different demographic populations as seen in Tables 1 and 2. Addition of the Cottage Grove workforce, that was actively engaged in the manufacture of the ammonium salt of perfluorooctanoic acid and had the highest serum PFOA concentrations of the three facilities, only further demonstrated the lack of an association between PFOA and cholesterol in this workforce. Unlike rats and mice, there was no reduction in serum cholesterol in cynomolgus monkeys dosed with PFOA (ammonium salt) for 6 months (Butenhoff et al. 2002).

A weakly negative association was observed with HDL that was possibly due to uncontrolled (i.e., residual) confounding, based on lower HDL values observed among the Cottage Grove and Decatur workers than the Antwerp workers and their markedly different demographic factors (e.g., BMI). When the analyses were stratified by location, no statistically significant associations were observed between HDL and PFOA. In another occupational study, Kaplan (2004) did not report an association between HDL and serum PFOA concentrations. Neither did Emmett et al. (2006a) in a community-based exposure study whose median PFOA concentrations (approximately $0.354 \mu \mathrm{g} / \mathrm{ml}$ ) were 60 times higher than that of general population studies (Calafat et al. 2006; Olsen et al. 2003b). To further clarify any possible association with HDL, the A apolipoproteins, which form the major proteins found in HDL, could be measured although this was not part of the present study. Apolipoprotein A1 was not associated with serum PFOA of comparable concentrations in a small analysis of Italian production workers (Costa 2004).

Serum triglyceride levels were positively associated with PFOA. Although a biological association cannot be ruled out, it is also possible that this association might have been due, at least partially, to residual confounding as a consequence of the disproportionate number of Cottage Grove and Decatur employees with higher PFOA concentrations than the Antwerp employees. The same positive association was also observed between PFOS and serum 


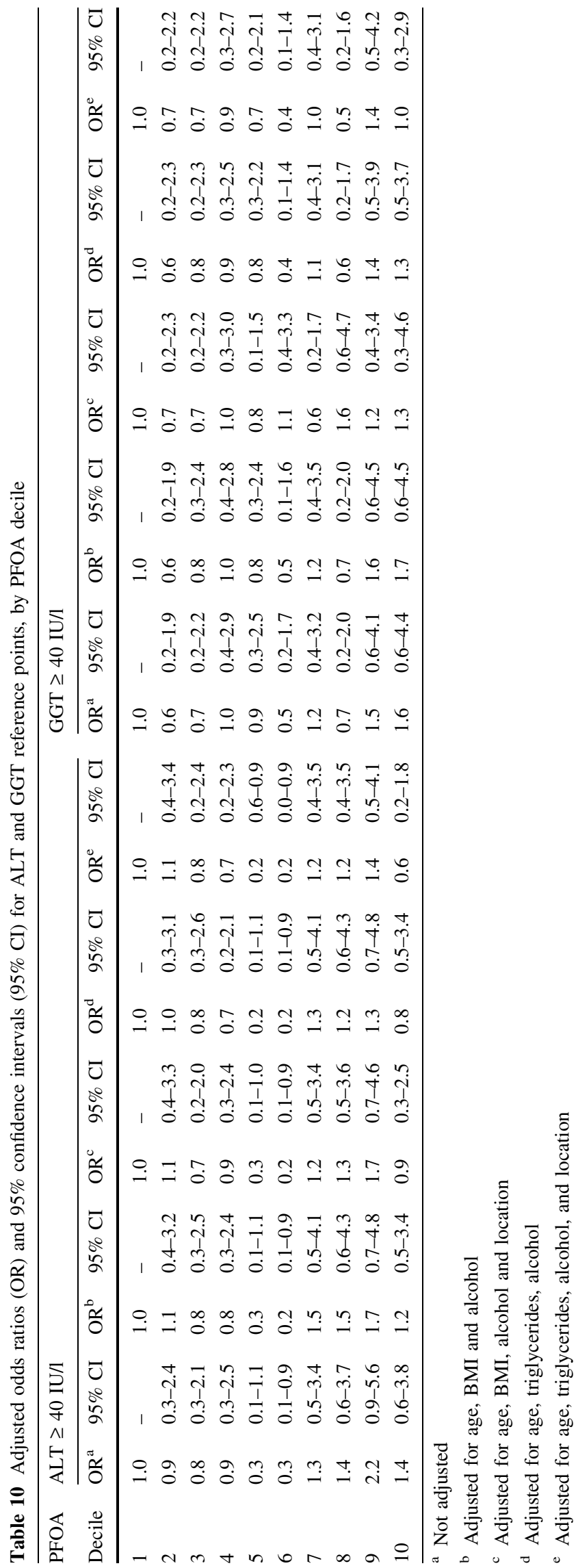

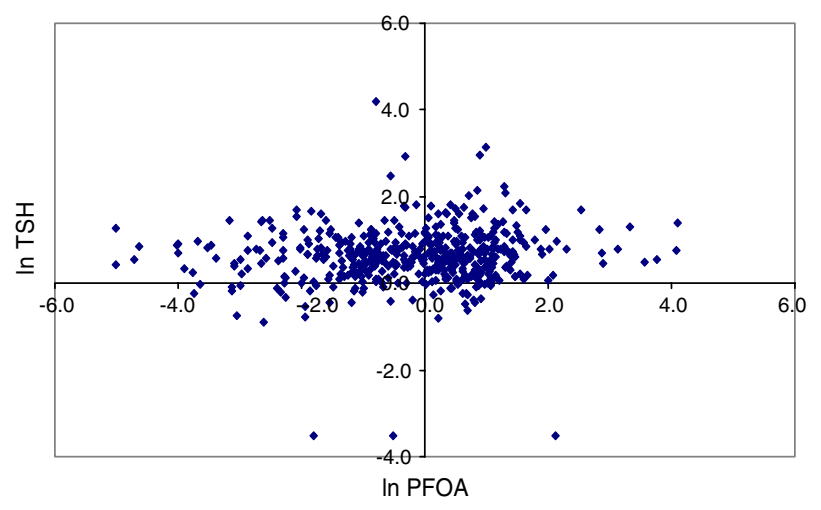

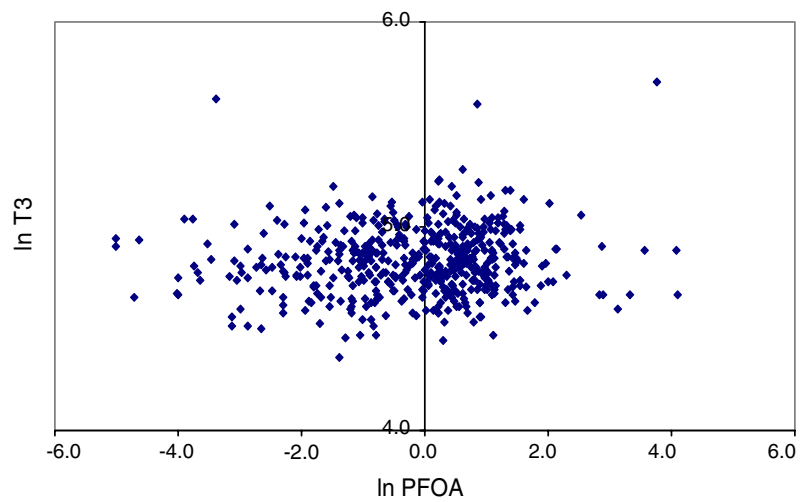

Fig. 5 Scatterplots of the natural $\log$ PFOA (ng/ml) by the natural $\log \mathrm{TSH}$ and T3

triglycerides (Olsen et al. 2003c). This prior association with PFOS is inconsistent with the well-established hypolipidemia reported in PFOS-related toxicological studies with concentrations much higher than in the present study (Seacat et al. 2002, 2003). On the other hand, PFOA was statistically significantly positively associated with triglycerides in the high-dose $(30 / 20 \mathrm{mg} / \mathrm{kg}$ ) monkey group whose steady state serum PFOA concentration was $158 \pm 10 \mu \mathrm{g} / \mathrm{ml}$ (range 20-467 $\mu \mathrm{g} / \mathrm{ml}$ ) (Butenhoff et al. 2002). This association was observed in measurements taken after 1 month of dosing at which time the group mean triglyceride level was significantly higher than control values as well as within group pretreatment values. At the end of the study the mean triglyceride was elevated compared to time related controls but not to the animals' pre-treatment values. However, only two primates were evaluated in the high-dose group at end of study. Inspection of individual values for PFOA serum concentration and serum triglyceride values did not reveal any meaningful associations between these two parameters.

Of the four lipid measurements assessed in this study, serum triglycerides have three times more intra-individual biological variation than either total cholesterol, LDL, or HDL (Stein and Myers 1994). Serum triglycerides are influenced by obesity, alcohol intake, and inattention to 

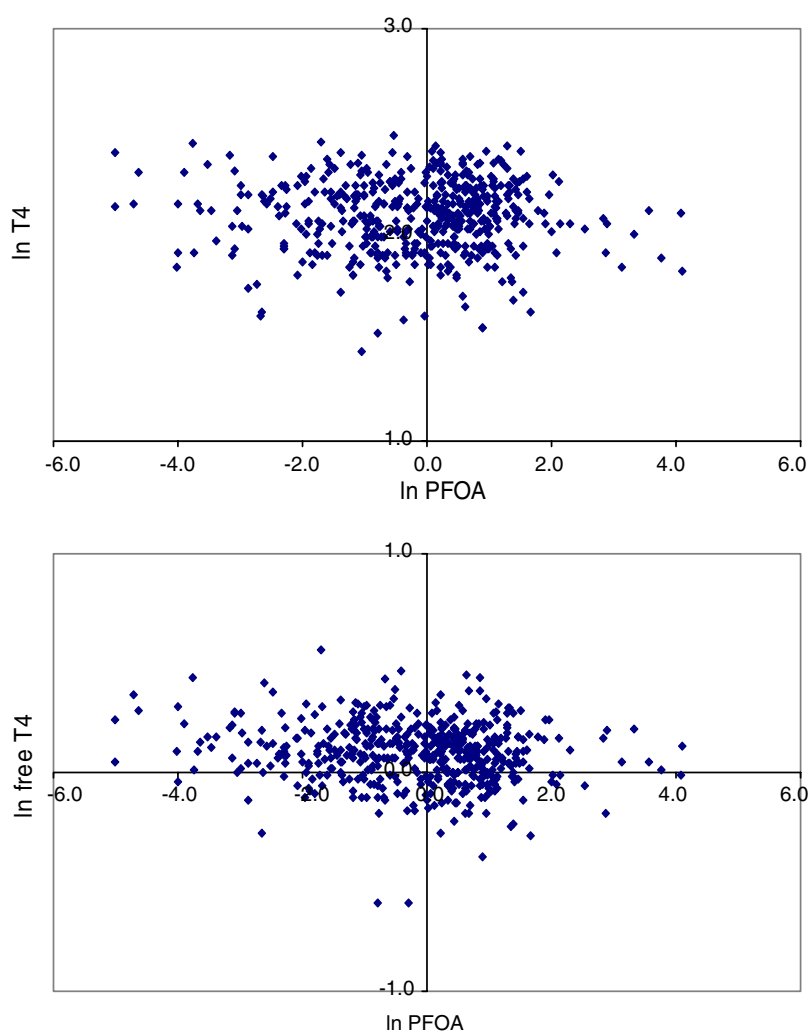

Fig. 6 Scatterplots of the natural $\log$ PFOA $(\mathrm{ng} / \mathrm{ml})$ by the natural $\log \mathrm{T} 4$ and free $\mathrm{T} 4$ fasting requirements for blood collection, including caffeinated drinks. It can also be hypothesized that the associations observed for serum triglycerides and PFOA might be the consequence of the non-adherence to fasting requirements by some shift production workers and/or the effect of postprandial metabolic responses in shift workers. Several studies have indicated postprandial serum triglyceride levels are higher among night shift workers than day workers (Al-Naimi et al. 2004; Morgan et al. 1998; Karlsson et al. 2001; Lund et al. 2001). If a subset of subjects (i.e., production workers with higher PFOA serum concentrations) who worked night shift were less likely to adhere to the fasting requirements and/or have postprandial metabolic profiles similar to other night shift workers, then a non-causal positive association between PFOA concentrations and serum triglycerides could be observed when all subjects are included in the analysis. Unfortunately, at the time of data blood collection shift status information was not obtained; consequently with this database it is not possible to further address this methodological question. Countering this possible hypothesis is the fact that blood glucose, also requiring a fasting sample, was not associated with PFOA at any site. However, hyperglycemia has not been consistently associated with night shift workers (Al-Naimi et al. 2004; Karlsson et al. 2003). Also, the association between serum triglycerides and PFOA was not
Table 11 Non-adjusted and adjusted natural $\log (\ln )$ PFOA coefficients with ln thyroidrelated hormone measurements a See study methods. Adjusted for Ln age, Ln BMI, Ln alcohol

\begin{tabular}{|c|c|c|c|c|c|c|}
\hline & \multicolumn{3}{|c|}{$\begin{array}{l}\text { Non-adjusted } \\
\text { Ln PFOA }\end{array}$} & \multicolumn{3}{|l|}{$\begin{array}{l}\text { Adjusted }^{\mathrm{a}} \\
\text { Ln PFOA }\end{array}$} \\
\hline & Coefficient & SE & $P$ value & Coefficient & $\mathrm{SE}$ & $P$ value \\
\hline \multicolumn{7}{|l|}{ Ln TSH } \\
\hline All locations & 0.0395 & 0.0204 & 0.05 & 0.0360 & 0.0207 & 0.08 \\
\hline Antwerp & 0.0509 & 0.0329 & 0.12 & 0.0391 & 0.0333 & 0.24 \\
\hline Cottage Grove & -0.0016 & 0.0310 & 0.96 & -0.0111 & 0.0322 & 0.73 \\
\hline Decatur & 0.0343 & 0.0497 & 0.49 & 0.0365 & 0.0513 & 0.48 \\
\hline \multicolumn{7}{|l|}{ Ln T4 } \\
\hline All locations & -0.0037 & 0.0054 & 0.50 & -0.0057 & 0.0054 & 0.29 \\
\hline Antwerp & -0.0022 & 0.0099 & 0.83 & -0.0041 & 0.0099 & 0.68 \\
\hline Cottage Grove & -0.0124 & 0.0072 & 0.09 & -0.0093 & 0.0072 & 0.20 \\
\hline Decatur & -0.0012 & 0.0126 & 0.92 & -0.0083 & 0.0127 & 0.51 \\
\hline \multicolumn{7}{|l|}{$\mathrm{Ln}$ free $\mathrm{T} 4$} \\
\hline All locations & -0.0138 & 0.0044 & 0.002 & -0.0117 & 0.0043 & 0.01 \\
\hline Antwerp & -0.0108 & 0.0078 & 0.17 & -0.0140 & 0.0078 & 0.07 \\
\hline Cottage Grove & -0.0093 & 0.0058 & 0.11 & -0.0071 & 0.0059 & 0.23 \\
\hline Decatur & -0.0138 & 0.0103 & 0.18 & -0.0184 & 0.0105 & 0.08 \\
\hline \multicolumn{7}{|l|}{ Ln T3 } \\
\hline All locations & 0.0107 & 0.0052 & 0.04 & 0.0105 & 0.0053 & 0.05 \\
\hline Antwerp & 0.0222 & 0.0077 & 0.005 & 0.0216 & 0.0077 & 0.006 \\
\hline Cottage Grove & 0.0026 & 0.0096 & 0.79 & 0.0006 & 0.0099 & 0.95 \\
\hline Decatur & 0.0317 & 0.0117 & 0.008 & 0.0271 & 0.0119 & 0.02 \\
\hline
\end{tabular}


Table 12 Predicted thyroid-related measurements (reference range in parentheses) based on regression models for 40 year-old male with $\mathrm{BMI}=28$, and consumes 0.5 alcoholic drinks per day

\begin{tabular}{lllll}
\hline $\begin{array}{l}\text { PFOA } \\
(\mu \mathrm{g} / \mathrm{ml})\end{array}$ & $\begin{array}{l}\text { Predicted } \\
\text { TSH }(\mu \mathrm{IU} / \mathrm{ml}) \\
(0.25-5.5)\end{array}$ & $\begin{array}{l}\text { Predicted } \\
\mathrm{T} 4(\mu \mathrm{g} / \mathrm{dl}) \\
(4.5-12.0)\end{array}$ & $\begin{array}{l}\text { Predicted } \\
\text { free T4 } \\
(\mathrm{ng} / \mathrm{dl})\end{array}$ & $\begin{array}{l}\text { Predicted } \\
(0.70-1.53) \\
(60-181)\end{array}$ \\
\hline 0.005 & 1.58 & 8.22 & 1.15 & 119 \\
0.01 & 1.62 & 8.19 & 1.15 & 119 \\
0.10 & 1.76 & 8.08 & 1.11 & 121 \\
0.50 & 1.87 & 8.01 & 1.09 & 124 \\
1.00 & 1.91 & 7.98 & 1.09 & 125 \\
5.00 & 2.03 & 7.90 & 1.06 & 128 \\
10.00 & 2.07 & 7.87 & 1.06 & 128 \\
50.00 & 2.20 & 7.80 & 1.04 & 131 \\
100.00 & 2.26 & 7.77 & 1.03 & 132 \\
\hline
\end{tabular}

observed at the Cottage Grove site which had both production and non-production workers. Nevertheless, a positive association between serum triglycerides and PFOA was reported by Kaplan (2004) whose study population also consisted of production (shift workers) and non-production (non-shift workers) participants. To further clarify a possible positive association, between workers' PFOA concentrations and serum triglyceride levels, adjustment for shift work becomes a methodological necessity for subsequent occupational research analyses.

Although hepatic enzymes, in particular GGT, AST and ALT are known to be elevated with heavy alcohol consumption, these liver enzymes can also be elevated due to obesity and dyslipidemia (Collantes et al. 2004; Mofrad and Sanyal 2003; Ruhl and Everhart 2003) as non-alcoholic fatty liver disease has substantially increased in prevalence in the US population, as indicated by the third National Health and Nutrition Examination Survey (NHANES) (Clark et al. 2003). Measured hepatic clinical chemistry enzymes in the present study were not consistently associated with employees' serum PFOA concentrations adjusted for age, alcohol, and either BMI or serum triglycerides. A weakly positive association between alkaline phosphatase, ALT and GGT with PFOA was observed among the Decatur male participants. Several epidemiologic research studies of the Decatur workforce have not reported associations with liver disease (malignant or non-malignant conditions) using a variety of data sources including death certificates (Alexander et al. 2003), episodes of care (Olsen et al. 2004) and self-reports (Alexander and Grice 2006). Neither a worker population study (Kaplan 2004) nor a community-based PFOA-exposed population (Emmett et al. 2006a, b) has reported associations between PFOA and hepatic clinical chemistries. In the Emmett et al. (2006a) study, there was no relationship between the blood levels of PFOA and the results for cholesterol, hepatic-related tests (serum protein, albumin, bilirubin, serum alkaline phosphatase, AST, ALT and GGT), or being treated for or informed by a physician that a community participant had liver disease (cirrhosis, hepatitis, and any other liver condition).

In the present study, there were no consistent associations between TSH, T4, free T4 or T3 with PFOA across the individual facility locations. Overall, T4 was negatively associated with PFOA and T3 was positively associated but these trends were well within normal reference ranges. The lack of thyroid related hormone associations is also consistent with results from Kaplan (2004) and Emmett et al. (2006a). In a 6-month oral capsule PFOA dose study of cynomolgus monkeys, Butenhoff et al. (2002) reported no

Table 13 Adjusted mean and 95\% confidence intervals for thyroid measurements, by PFOA decile

\begin{tabular}{|c|c|c|c|c|c|c|c|c|}
\hline \multirow{2}{*}{$\begin{array}{l}\text { PFOA } \\
\text { Decile }\end{array}$} & \multicolumn{2}{|l|}{ TSH } & \multicolumn{2}{|l|}{$\mathrm{T} 4$} & \multicolumn{2}{|l|}{ Free T4 } & \multicolumn{2}{|l|}{ T3 } \\
\hline & Mean & $95 \% \mathrm{CI}$ & Mean & $95 \% \mathrm{CI}$ & Mean & $95 \% \mathrm{CI}$ & Mean & $95 \% \mathrm{CI}$ \\
\hline 1 & $2.07^{\mathrm{d}}$ & $1.13-3.01$ & 8.29 & $7.92-8.66$ & $1.15^{\mathrm{e}, \mathrm{g}, \mathrm{j}}$ & $1.11-1.19$ & 124 & $118-131$ \\
\hline 2 & $2.00^{\mathrm{d}}$ & $1.04-2.96$ & 8.45 & $8.07-8.83$ & 1.11 & $1.07-1.15$ & 125 & 118-131 \\
\hline 3 & $1.89^{\mathrm{d}}$ & $0.94-2.84$ & 8.08 & $7.70-8.46$ & $1.14^{\mathrm{e}, \mathrm{j}}$ & $1.10-1.18$ & 124 & $118-131$ \\
\hline 4 & $3.43^{\mathrm{a}-\mathrm{c}, \mathrm{f}}$ & $2.48-4.38$ & 8.04 & $7.67-8.41$ & 1.12 & $1.08-1.16$ & 126 & $120-133$ \\
\hline 5 & 2.61 & $1.65-3.55$ & $7.98^{\mathrm{f}}$ & $7.60-8.35$ & $1.07^{\mathrm{a}, \mathrm{c}}$ & $1.03-1.11$ & 126 & $120-133$ \\
\hline 6 & $2.07^{\mathrm{d}}$ & $1.11-3.03$ & $8.53^{\mathrm{e}, \mathrm{j}}$ & $8.15-8.91$ & 1.10 & $1.05-1.14$ & 128 & $121-134$ \\
\hline 7 & 2.21 & $1.26-3.16$ & 8.07 & $7.70-8.44$ & $1.09^{\mathrm{a}}$ & $1.06-1.14$ & 129 & $123-135$ \\
\hline 8 & 2.36 & $1.46-3.32$ & 8.40 & $8.03-8.76$ & 1.08 & $1.06-1.14$ & 130 & $124-136$ \\
\hline 9 & 2.84 & $1.87-3.81$ & 8.42 & $8.03-8.80$ & 1.11 & $1.06-1.15$ & 129 & $123-136$ \\
\hline 10 & 2.40 & $1.46-3.37$ & $7.94^{\mathrm{f}}$ & $7.56-8.32$ & $1.07^{\mathrm{a}, \mathrm{c}}$ & $1.03-1.11$ & 128 & $123-136$ \\
\hline
\end{tabular}

Adjusted for age, BMI and alcohol

${ }^{\mathrm{a}-\mathrm{j}}$ Statistically significantly $(P<0.05)$ different than PFOA decile(s) $1,2,3, \ldots, 10$, respectively 
clear changes in thyroid hormone homeostasis for TSH, T4 or free T4. Three high-dose monkeys (serum concentrations mentioned above) that were removed from dosing due to toxicity had T3 values that trended downward compared to pretreatment measures. This is opposite the observation in the present study. Finally, a negative bias in thyroidrelated analog methods, using another perfluoroalkyl acid (PFOS), has recently been reported by Chang et al. (2007).

\section{Conclusion}

PFOA concentrations measured in this workforce of 506 male fluorochemical production workers were not associated with total cholesterol, LDL, hepatic enzymes or thyroid hormones. Residual confounding likely explained an association between PFOA and HDL. Several hypotheses are offered for the inconsistent associations observed between PFOA and triglycerides. Although a biological explanation cannot be ruled out, other hypotheses are also plausible. These include non-adherence to fasting requirements for morning blood collection by night shift production workers and/or increased triglyceride levels that have been found in night shift workers, in general. Because PFOA has been shown to bind or be carried to blood albumin and beta-lipoproteins in the rat, monkey and human, a non-causal positive correlation also remains another possible explanation.

\section{References}

Alexander BH, Grice M (2006) Self-reported medical conditions in perfluorooctanesulfonyl fluoride manufacturing workers. University of Minnesota, Minneapolis, 1 February, 2006. US EPA docket AR-226-3677. US Environmental Protection Agency, Washington, DC

Alexander BH, Olsen GW, Burris JM, Mandel JH, Mandel JS (2003) Mortality of employees of a perfluorooctanesulphonyl fluoride manufacturing facility. Occup Environ Med 60:722-729

Al-Naimi S, Hampton SM, Richard P, Tzung C, Morgan LM (2004) Postprandial metabolic profiles following meals and snacks eaten during simulated night and day shift work. Chronobiol Int 21:937-947

Brousseau ME, Schaefer EJ, Wolfe ML, Bloedon LT, Digenio AG, Clark RW, Mancuso JP, Rader DJ (2004) Effects of an inhibitor of cholesteryl ester transfer protein on HDL cholesterol. N Engl J Med 350:1505-1515

Butenhoff J, Costa G, Elcombe C, Farrar D, Hansen K, Iwai H, Jung R, Kennedy G, Lieder P, Olsen G, Thomford P (2002) Toxicity of ammonium perfluorooctanoate in male cynomolgus monkeys after oral dosing for 6 months. Toxicol Sci 69:244-257

Calafat AM, Kuklenyik Z, Caudill SP, Reidy JA, Needham LL (2006) Perfluorochemicals in pooled serum samples from United States residents in 2001 and 2002. Environ Sci Technol 40:2128-2134

Chang SC, Thibodeaux JR, Eastvold ML, Ehresman DJ, Bjork JA, Froehlich JW, Lau CS, Singh RJ, Wallace KB, Butenhoff JL (2007) Negative bias from analog methods used in the analysis of free thyroxine in rat serum containing perfluorooctanesulfonate (PFOS). Toxicology 234:21-33

Clark JM, Brancati FL, Diehl AM (2003) The prevalence and etiology of elevated aminotransferase levels in the United States. Am J Gastroenterol 98:960-967

Collantes R, Ong JP, Younossi ZM (2004) Nonalcoholic fatty liver disease and the epidemic of obesity. Cleve Clin J Med 71:657-664

Costa G (2004) Letter. US EPA docket AR226-1868. US Environmental Protection Agency, Washington, DD

De Silva AO, Mabury SA (2006) Isomer distribution of perfluorocarboxylates in human blood: potential correlation to source. Environ Sci Technol 40:2903-2909

Emmett EA, Zhang H, Shofer FS, Freeman D, Rodway NV, Desai C, Shaw LM (2006a) Community exposure to perfluorooctanoate: relationships between serum levels and certain health parameters. JOEM 48:771-779

Emmett EA, Zhang H, Shofer FS, Freeman D, Rodway NV, Desai C, Shaw LM (2006b) Community exposure to perfluorooctanoate: relationships between serum concentrations and exposure sources. JOEM 48:759-770

Expert Panel (2001) Executive summary of the third report of the National Cholesterol Education Program (CNCEP) Expert Panel on detection, evaluation, and treatment of high blood cholesterol in adults (Adult Treatment Panel III). JAMA 285:2486-2497

Friedewald WT, Levy RI, Fredrickson DS (1972) Estimation of the concentration of low-density lipoprotein cholesterol in plasma without use of the preparative ultracentrifuge. Clin Chem 18:499-502

Gilliland FD, Mandel JS (1996) Serum perfluorooctanoic acid and hepatic enzymes, lipoproteins and cholesterol: a study of occupationally exposed men. Am J Ind Med 129:560-568

Han X, Snow TA, Kemper RA, Jepson GW (2003) Binding of perfluorooctanoic acid to rat and human plasma proteins. Chem Res Toxicol 16:775-781

Hansen KJ, Clemen LA, Ellefson ME, Johnson HO (2001) Compound-specific quantitative characterization of organic fluorochemicals in biological matrices. Environ Sci Technol 35:766-770

Hernán MA, Hernández-Diaz S, Werler MM, Mitchell AA (2002) Causal knowledge as a prerequisite for confounding evaluation: an application to birth defects epidemiology. Am J Epidemiol 155:176-184

Kaplan AM (2004) Ammonium perfluorooctanoate. US EPA docket AR-226-1867 and AR 226-1868. US Environmental Protection Agency, Washington, DC

Karlsson B, Knutsson A, Lindahl B (2001) Is there an association between shift work and having a metabolic syndrome? Results from a population based study of 27,485 people. Occup Environ Med 58:747-752

Karlsson BH, Knutsson AK, Lindahl BO, Alfredsson LS (2003) Metabolic disturbances in male workers with rotating three-shift work. Results of the WOLF study. Int Arch Occup Environ Health 76:424-430

Kennedy GL, Butenhoff JL, Olsen GW, O'Connor JC, Seacat AM, Perkins RG, Biegel LB, Murphy SR, Farrar DG (2004) The toxicology of perfluorooctanoate. Crit Rev Toxicol 34:351-384

Kerstner-Wood C, Coward L, Gorman G (2003) Protein binding of perfluorobutane sulfonate, perfluorohexane sulfonate, perfluorooctane sulfonate and perfluorooctanoate to plasma (human, rat, and monkey), and various human-derived plasma protein fractions. Southern Research Institute. Study 9921.7. US EPA docket AR-226-1354. US Environmental Protection Agency, Washington, DC

Lund J, Arendt J, Hampton SM, English J, Morgan LM (2001) Postprandial hormone and metabolic responses amongst shift workers in Antarctica. J Endocrinol 171:557-564 
Maloney EK, Waxman DJ (1999) Transactivation of PPAR $\alpha$ and PPAR $\gamma$ by structurally diverse environmental chemicals. Toxicol Appl Pharmacol 161:209-218

Mofrad PS, Sanyal AJ (2003) Nonalcoholic fatty liver disease. MedGenMed 5:1-13

Morgan L, Arendt J, Owens D, Folkard S, Hampton S, Deacon S, English J, Ribeiro D, Taylor K (1998) Effects of the endogenous clock and sleep time on melatonin, insulin, glucose, and lipid metabolism. J Endocrinol 157:443-451

Nakanishi N, Matsuo Y, Yoneda H, Nakamur K, Suzuki K, Tatara K (2000) Validity of the conventional indirect methods including Friedewald method for determining serum low-density lipoprotein cholesterol level: comparison with the direct homogeneous enzymatic analysis. J Occup Health 42:130-137

Olsen GW, Zobel LR (2006) An analysis of the 2000 fluorochemical (perfluorooctanoate, PFOA) medical surveillance program at $3 \mathrm{M}$ Company's Antwerp (Belgium), Cottage Grove (Minnesota), and Decatur (Alabama) facilities. 3M Company, St Paul, 6 May, 2006. US EPA docket AR-226-3678. US Environmental Protection Agency, Washington, DC

Olsen GW, Gilliland FD, Burlew MM, Burris JM, Mandel JS, Mandel JH (1998) An epidemiologic investigation of reproductive hormones in men with occupational exposure to perfluorooctanoic acid. JOEM 40:614-622

Olsen GW, Burris JM, Mandel JH, Zobel LR (1999) Serum perfluorooctane sulfonate and hepatic and lipid clinical chemistry tests in fluorochemical production employees. JOEM 42:799-806

Olsen GW, Burris JM, Burlew MM, Mandel JH (2000) Plasma cholecystokinin and hepatic enzymes, cholesterol and lipoproteins in ammonium perfluorooctanoate production workers. Drug Chem Toxicol 23:603-620

Olsen GW, Burris JM, Burlew MM, Mandel JH (2003a) Epidemiologic assessment of worker serum perfluorooctanesulfonate (PFOS) and perfluorooctanoate (PFOA) concentrations and medical surveillance examinations. JOEM 45:260-270
Olsen GW, Church TR, Miller JP, Burris JM, Hansen KJ, Lundberg JK, Armitage JB, Herron RM, Medhdizadehkashi Z, Nobiletti JB, O'Neill EM, Mandel JH, Zobel LR (2003b) Perfluorooctanesulfonate and other fluorochemicals in the serum of American Red Cross adult blood donors. Environ Health Perspect 111:1892-1901

Olsen GW, Butenhoff JL, Mandel JH (2003c) Assessment of lipid, hepatic and thyroid function in relation to an occupational biologic limit value for perfluorooctanoate. 3M Company, St Paul. US EPA docket AR-226-1351. US Environmental Protection Agency, Washington, DC

Olsen GW, Burlew MM, Marshall JC, Burris JM, Mandel JH (2004) Analysis of episodes of care in a perfluorooctanesulfonyl fluoride production facility. JOEM 46:837-846

Ruhl CE, Everhart JE (2003) Determinants of the association of overweight with elevated serum alanine aminotransferase activity in the United States. Gastroenterology 124:71-79

Seacat AM, Thomford PJ, Hansen KJ, Olsen GW, Case MT, Butenhoff JL (2002) Subchronic toxicity studies on perfluorooctanesulfonate potassium salt in cynomolgus monkeys. Toxicol Sci 68:249-264

Seacat AM, Thomford PJ, Hansen KJ, Clemens LA, Eldridge SR, Elcombe CR, Butenhoff JL (2003) Sub-chronic dietary toxicity of potassium perfluorooctanesulfonate in rats. Toxicology 183:117-131

Stein EA, Myers GL (1994) Lipids, lipoproteins, and apolipoproteins. In: Burtis CA, Ashwood ER (eds) Tietz textbook of clinical chemistry. WB Saunders Co., Philadelphia, pp 1002-1093

Ubel FA, Sorenson SD, Roach DE (1980) Health status of plant workers exposed to fluorochemicals-a preliminary report. Am Ind Hyg Assoc J 41:584-589

Xie Y, Yang Q, Nelson BD, DePierre JW (2003) The relationship between liver peroxisome proliferation and adipose tissue atrophy induced by peroxisome proliferators exposure and withdrawal in mice. Biochem Pharmacol 66:749-756 